\title{
Detection and Characterization of Mononuclear
}

\section{Pd(I) Complexes}

Jia Luo, ${ }^{*}$ Nigam P. Rath, ${ }^{\#}$ and Liviu M. Mirica* ${ }^{*}$

$\dagger$ Department of Chemistry, University of Illinois at Urbana-Champaign, 600 S. Mathews Avenue, Urbana, Illinois 61801, United States

Department of Chemistry, Washington University, One Brookings Drive, St. Louis, Missouri 63130-4899.

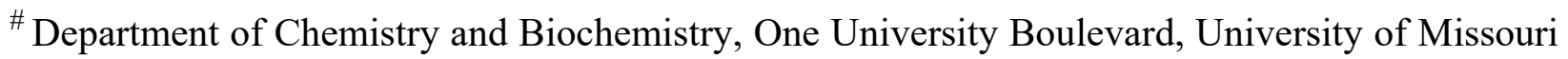
- St. Louis, Missouri 63121-4400

*Correspondence: mirica@illinois.edu (L.M.M)

\begin{abstract}
Palladium is a versatile transition metal used to catalyze a large number of chemical transformations, largely due to its ability to access various oxidation states (0, I, II, III, and IV). Among these oxidation states, $\operatorname{Pd}(\mathrm{I})$ is arguably the least studied, and while dinuclear $\operatorname{Pd}(\mathrm{I})$ complexes are more common, mononuclear Pd(I) species are very rare. Reported herein are spectroscopic studies of a series of Pd(I) intermediates generated by the chemical reduction of $\operatorname{Pd}(\mathrm{II})$ precursors supported by the tetradentate ligands 2,11-dithia[3.3](2,6)pyridinophane
\end{abstract}


$(\mathrm{N} 2 \mathrm{~S} 2)$

and

$N, N^{\prime}$-di-tert-butyl-2,11-diaza[3.3](2,6)pyridinophane

$\left({ }^{\mathrm{B} u} \mathrm{~N} 4\right)$ :

$\left[(\mathrm{N} 2 \mathrm{~S} 2) \mathrm{Pd}^{\mathrm{II}}(\mathrm{MeCN})\right]_{2}(\mathrm{OTf})_{4} \quad(\mathbf{1}), \quad\left[(\mathrm{N} 2 \mathrm{~S} 2) \mathrm{Pd}^{\mathrm{II}} \mathrm{Me}_{2}(\mathrm{OTf})_{2} \quad(\mathbf{2}), \quad\left[(\mathrm{N} 2 \mathrm{~S} 2) \mathrm{Pd}^{\mathrm{II}} \mathrm{Cl}\right](\mathrm{OTf})\right.$ $\left[(\mathrm{N} 2 \mathrm{~S} 2) \mathrm{Pd}^{\mathrm{II}} \mathrm{X}\right](\mathrm{OTf})_{2} \quad\left(\mathrm{X}=\mathrm{tBuNC} \quad \mathbf{4}, \quad \mathrm{PPh}_{3} \quad\right.$ 5), $\left[(\mathrm{N} 2 \mathrm{~S} 2) \mathrm{Pd}^{\mathrm{II}} \mathrm{Me}(\mathrm{PPh} 3)\right](\mathrm{OTf}) \quad(6)$, and $\left[\left({ }^{\mathrm{tBu}} \mathrm{N} 4\right) \mathrm{Pd}^{\mathrm{II}} \mathrm{X}_{2}\right](\mathrm{OTf})_{2}(\mathrm{X}=\mathrm{MeCN} \mathbf{8}, \mathrm{tBuNC}$ 9). In addition, a stable Pd(I) dinuclear species, $\left[(\mathrm{N} 2 \mathrm{~S} 2) \mathrm{Pd}^{\mathrm{I}}(\mu-\mathrm{BuNC})\right]_{2}\left(\mathrm{ClO}_{4}\right)_{2}(7)$, was isolated upon the electrochemical reduction of 4 and structurally characterized. Moreover, the $\left({ }^{\mathrm{tBu}} \mathrm{N} 4\right) \mathrm{Pd}^{\mathrm{I}}$ intermediates, formed from the chemical reduction of $\left[\left({ }^{\mathrm{tBu}} \mathrm{N} 4\right) \mathrm{Pd}^{\mathrm{II}} \mathrm{X}_{2}\right](\mathrm{OTf})_{2}(\mathrm{X}=\mathrm{MeCN} 8, \mathrm{tBuNC} 9)$ complexes, were investigated by EPR spectroscopy, X-ray absorption spectroscopy (XAS), and DFT calculations, and compared with the analogous (N2S2)Pd ${ }^{\mathrm{I}}$ systems. Upon probing the stability of $\mathrm{Pd}(\mathrm{I})$ species under various ligand environments ( $\mathrm{N} 2 \mathrm{~S} 2$ and $\left.{ }^{\mathrm{tBu}} \mathrm{N} 4\right)$, it is apparent that the presence of soft ligands such as tBuNC and $\mathrm{PPh}_{3}$ significantly improves the stability of $\mathrm{Pd}(\mathrm{I})$ species, which should make the isolation of mononuclear $\mathrm{Pd}(\mathrm{I})$ species possible.

\section{Keywords}

Pd(I) complexes; multidentate ligands; EPR; electrochemistry; X-ray absorption spectroscopy.

\section{INTRODUCTION}

Palladium is a versatile transition metal used to catalyze a large number of chemical transformations, largely due to its ability to access various oxidation states (0, I, II, III, and IV). The $\operatorname{Pd}(0)$ and $\operatorname{Pd}(\mathrm{II})$ systems are by far the most exstensively studied for catalytic applications, ${ }^{1}$ and the chemistry of high-valent $\mathrm{Pd}(\mathrm{III})$ and $\mathrm{Pd}(\mathrm{IV})$ complexes has also received significant attention in the past few years. ${ }^{2}$ Since 2004 when Sanford's group first showed the involvement of $\mathrm{Pd}(\mathrm{IV})$ species in catalytic C-H functionalization reactions, ${ }^{2 \mathrm{f}, 3}$ followed by the isolation of a $\mathrm{Pd}(\mathrm{III})-\mathrm{Pd}(\mathrm{III})$ dinuclear species as the intermediate for $\mathrm{C}-\mathrm{Cl}$ bond formation by Ritter's group in 
$2009,{ }^{4}$ extensive studies on Pd(III) and Pd(IV) complexes as the active intermediates of Pd catalyzed reactions have shed new light on the conventional Pd catalysis. ${ }^{2 h, 5}$ In previous studies, our group has reported a series of $\mathrm{Pd}(\mathrm{III})$ and $\mathrm{Pd}(\mathrm{IV})$ complexes, employing $N, N^{\prime}$-dialkyl-2,11diaza[3.3](2,6)pyridinophane $\left({ }^{\mathrm{R}} \mathrm{N} 4, \mathrm{R}=\mathrm{tBu}, \mathrm{iPr}, \mathrm{Me}\right), N^{\prime}, N^{\prime}, N^{\prime}$ '”-trimethyltriazacyclononane (Mestacn), and 2,11-dithia[3.3](2,6)- pyridinophane (N2S2) ligands. ${ }^{2 i,} 6$ Extensive reactivity studies have demonstrated the involvement of $\mathrm{Pd}(\mathrm{III})$ and $\mathrm{Pd}(\mathrm{IV})$ intermediates in the C-C and C-heteroatom bond formation reactions. Given our long-term interest in developing catalytic transformations employing odd-electron $\mathrm{Pd}(\mathrm{I})$ and $\mathrm{Pd}(\mathrm{III})$ species, ${ }^{7}$ we are actively targeting the synthesis and investigation of mononuclear $\mathrm{Pd}(\mathrm{I})$ complexes. While several reports describe the detection of transient mononuclear $\mathrm{Pd}(\mathrm{I})$ species, ${ }^{8}$ only one structurally characterized mononuclear Pd(I) cationic species has been reported independently by two research groups. ${ }^{9}$ An earlier report also described an isolated mononuclear $\mathrm{Pd}(\mathrm{I})$ complex, although the presence of a redox non-innocent ligand complicates the unambiguous Pd center oxidation state assignment. ${ }^{10}$ In addition, most of the isolated $\mathrm{Pd}(\mathrm{I})$ complexes reported to date are dinuclear $\mathrm{Pd}(\mathrm{I})$ species containing a $\operatorname{Pd}(\mathrm{I})-\mathrm{Pd}(\mathrm{I})$ bond, and thus are closed-shell systems. ${ }^{11}$ In this regard, reported herein are the spectroscopic studies of a series of $\mathrm{Pd}(\mathrm{I})$ intermediates generated by the chemical reduction of $\left[(\mathrm{N} 2 \mathrm{~S} 2) \mathrm{Pd}^{\mathrm{II}}(\mathrm{MeCN})\right]_{2}(\mathrm{OTf})_{4}(\mathbf{1}),\left[(\mathrm{N} 2 \mathrm{~S} 2) \mathrm{Pd}^{\mathrm{II}} \mathrm{Me}\right]_{2}(\mathrm{OTf})_{2}(\mathbf{2}),\left[(\mathrm{N} 2 \mathrm{~S} 2) \mathrm{Pd}^{\mathrm{II}} \mathrm{Cl}\right](\mathrm{OTf})$ (3), $\left[(\mathrm{N} 2 \mathrm{~S} 2) \mathrm{Pd}^{\mathrm{II} X}\right](\mathrm{OTf})_{2}\left(\mathrm{X}=\mathrm{tBuNC}^{4}, \mathrm{PPh}_{3}\right.$ 5), and $\left[(\mathrm{N} 2 \mathrm{~S} 2) \mathrm{Pd}^{\mathrm{II}} \mathrm{Me}\left(\mathrm{PPh}_{3}\right)\right](\mathrm{OTf})(\mathbf{6})$. In addition, a stable $\mathrm{Pd}(\mathrm{I})$ dinuclear species, $\left[(\mathrm{N} 2 \mathrm{~S} 2) \mathrm{Pd}^{\mathrm{I}}(\mu-\mathrm{tBuNC})\right]_{2}\left(\mathrm{ClO}_{4}\right)_{2}(7)$, was isolated upon the electrochemical reduction of 4 . Moreover, the $\left({ }^{\mathrm{tBu}} \mathrm{N} 4\right) \mathrm{Pd}^{\mathrm{I}}$ intermediates, formed from the

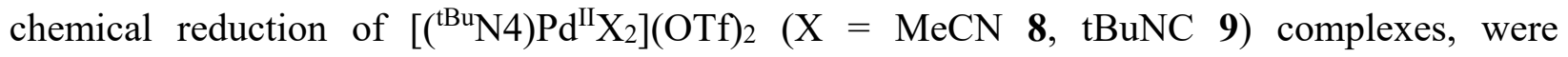
investigated by EPR spectroscopy, X-ray absorption spectroscopy (XAS), and DFT calculations, and compared with the analogous $(\mathrm{N} 2 \mathrm{~S} 2) \mathrm{Pd}^{\mathrm{I}}$ systems. Upon probing the stability of $\mathrm{Pd}(\mathrm{I})$ species 
under various ligand environments $\left(\mathrm{N} 2 \mathrm{~S} 2\right.$ and $\left.{ }^{\mathrm{tBu}} \mathrm{N} 4\right)$, it is apparent that the presence of soft ligands such as $\mathrm{tBuNC}$ and $\mathrm{PPh}_{3}$ significantly improves the stability of $\mathrm{Pd}(\mathrm{I})$ species, which should make the isolation of mononuclear $\operatorname{Pd}(\mathrm{I})$ species possible.

\section{RESULTS AND DISCUSSION}

\section{Synthesis and Characterization of Pd(II) Precursors}

The series of complexes $\left[(\mathrm{N} 2 \mathrm{~S} 2) \mathrm{Pd}^{\mathrm{II}}(\mathrm{MeCN})\right]_{2}(\mathrm{OTf})_{4}(\mathbf{1}),\left[(\mathrm{N} 2 \mathrm{~S} 2) \mathrm{Pd}^{\mathrm{II}} \mathrm{Me}\right]_{2}(\mathrm{OTf})_{2}$ (2), and $\left[(\mathrm{N} 2 \mathrm{~S} 2) \mathrm{Pd}{ }^{\mathrm{II}} \mathrm{Cl}\right](\mathrm{OTf})(\mathbf{3})$ were synthesized by following the previously reported procedures. ${ }^{6 e}, 12$ The addition of 2 equiv tBuNC or $\mathrm{PPh}_{3}$ to a $\mathrm{MeCN}$ solution of 1 generated complexes $\left[(\mathrm{N} 2 \mathrm{~S} 2) \mathrm{Pd}^{\mathrm{II}}(\mathrm{tBuNC})\right](\mathrm{OTf})_{2}$ (4) and $\left[(\mathrm{N} 2 \mathrm{~S} 2) \mathrm{Pd}^{\mathrm{II}}\left(\mathrm{PPh}_{3}\right)\right](\mathrm{OTf})_{2}$ (5) complexes, respectively, which were isolated as red crystals (Scheme 1). The X-ray crystal structures of $\mathbf{4}$ and $\mathbf{5}$ reveal that $\mathrm{Pd}(\mathrm{II})$ centers are in a distorted square pyramidal geometry with both $\mathrm{tBuNC}$ and $\mathrm{PPh}_{3}$ ligands replacing the $\mathrm{MeCN}$ molecule in the equatorial position, while the N2S2 ligand remains in the unusual $\kappa^{3}$ conformation (Figure 1). ${ }^{12} \mathrm{~A}$ significant intramolecular $\pi-\pi$ interaction between two pyridine rings was still observed, with the pyridine ring centroid-centroid interplanar distance of $3.44 \AA$ and $3.65 \AA$ for $\mathbf{4}$ and 5, respectively. ${ }^{13}$ However, in contrast to the dinuclear complexes $\mathbf{1}$ and 2, the Pd-Pd d $\mathrm{d}^{8}-\mathrm{d}^{8}$ interactions in $\mathbf{4}$ and $\mathbf{5}$ were no longer observed in the solid state, likely due to the steric effect of the $\mathrm{tBuNC}$ and $\mathrm{PPh}_{3}$ groups. The $\mathrm{Pd}-\mathrm{S}_{\text {ave }}$ bond lengths of $2.343 \AA$ for $\mathbf{4}$ and $2.330 \AA$ for $\mathbf{5}$ are comparable to those of $\mathbf{1}$ and $\mathbf{2}$, while the tilt angle of the pyridine ring vs the $\mathrm{Pd}-\mathrm{Nax}_{\mathrm{x}}$ bond in $\mathbf{5}$ of $52.8^{\circ}$ is smaller than that in $\mathbf{4}$ of $54.9^{\circ}$, consistent with the shorter bond length of Pd-Nax $(2.459 \AA)$ in 5 than that of $\mathbf{4}(2.573 \AA)$. Interestingly, the UVvis spectrum of a freshly prepared $\mathrm{MeCN}$ solution of $5(0.9 \mathrm{mM})$ exhibits an absorption band at $503 \mathrm{~nm}$, which slowly decays over the course of several hours (Figure 2), and a diluted solution 
of $5(0.09 \mathrm{mM})$ does not exhibit the $503 \mathrm{~nm}$ absorption band. The change of the UV-vis spectrum of $\mathbf{5}$ in solution suggests that the binding mode of the N2S2 ligand could change from a $\kappa^{3}$ conformation to a $\kappa^{2}$ conformation, with the $\mathrm{PPh}_{3}$ ligand and the two $\mathrm{N}$ donor atoms in the the equatorial plane, while two S atoms are weakly interacting (or not interacting at all) with the Pd center in the axial position. Such a conformation change process could be facilitated by the presence of coordinating solvent, as seen previously. ${ }^{12}$ The addition of $\mathrm{PPh}_{3}$ to a $\mathrm{MeCN}$ solution of 2 gives [(N2S2) $\left.\mathrm{Pd}^{\mathrm{II}} \mathrm{Me}\left(\mathrm{PPh}_{3}\right)\right](\mathrm{OTf})(\mathbf{6})$, isolated as almost colorless crystals. The X-ray crystal structure of $\mathbf{6}$ reveals a square-planar coordination at the $\mathrm{Pd}(\mathrm{II})$ center, with cis-positioned methyl and $\mathrm{PPh}_{3}$ groups, as well as a $\kappa^{2}$ conformation for N2S2 (Figure 1). ${ }^{6,14}$ The bond lengths of Pd-C (2.047 $\AA)$ and $\mathrm{Pd}-\mathrm{N}_{\mathrm{ave}}(2.158 \AA)$ are similar to $(\mathrm{N} 2 \mathrm{~S} 2) \mathrm{Pd}^{\mathrm{II}} \mathrm{Me}_{2}$, and the $\mathrm{Pd}-\mathrm{P}$ bond distance $(2.250 \AA)$ is also comparable to other reported values. ${ }^{15}$ This conformation change of $\mathrm{N} 2 \mathrm{~S} 2$ from $\kappa^{3}$ to $\kappa^{2}$ in the presence of $\mathrm{PPh}_{3}$ in $\mathbf{6}$ further confirms the possibility of a conformational change observed in the UV-vis spectra of $\mathbf{5}$.

Scheme 1. Synthesis of (N2S2)Pd ${ }^{\mathrm{II}}$ and (N2S2)Pd Complexes 


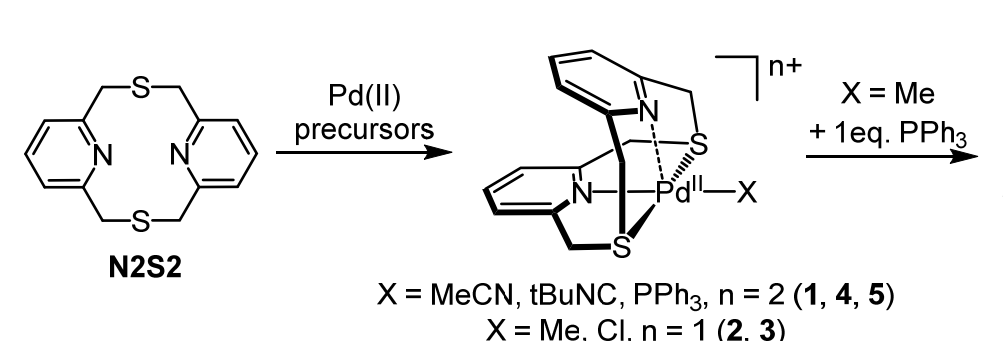

$\mathrm{X}=\mathrm{Me}, \mathrm{Cl}, \mathrm{n}=1(2,3)$
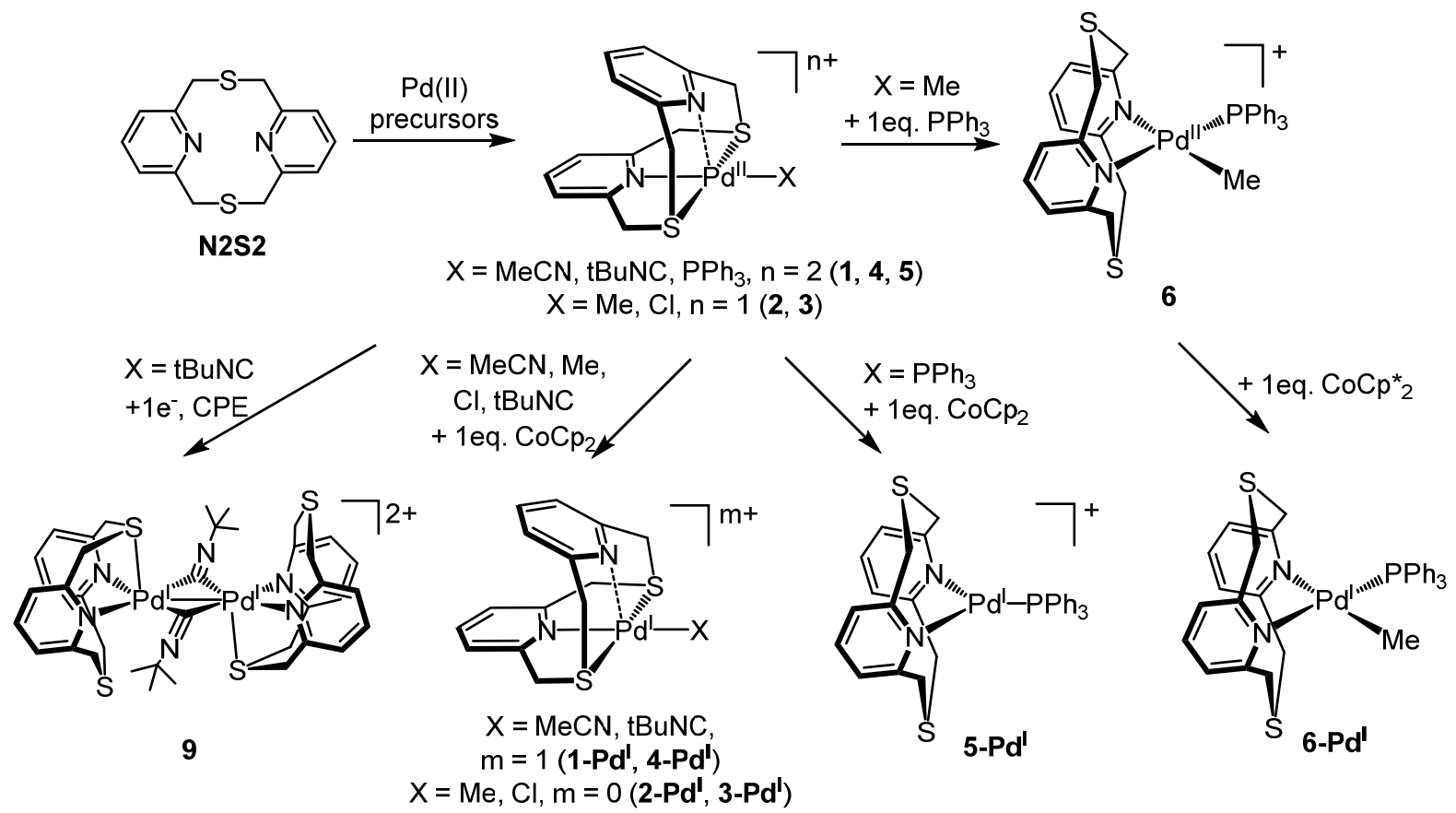

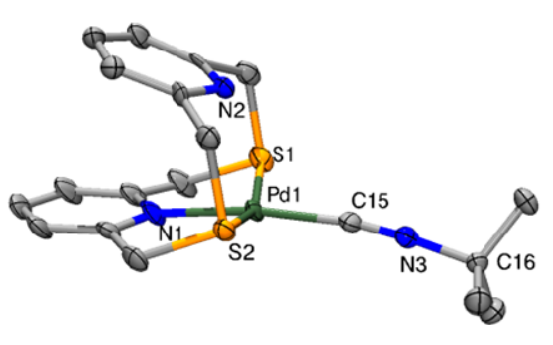

4

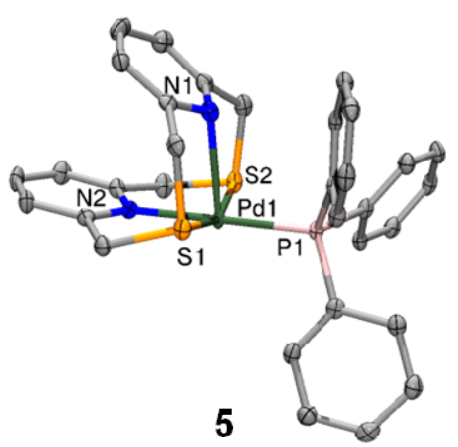

5

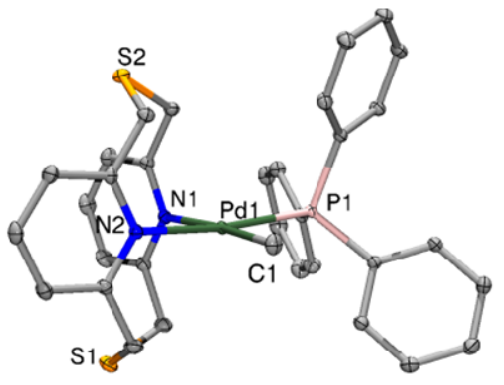

6

Figure 1. ORTEP diagrams for the dications of $\mathbf{4}, \mathbf{5}$, and $\mathbf{6}$, shown with $50 \%$ thermal ellipsoids and with the triflate counteranions and $\mathrm{H}$ atoms omitted for clarity. Selected bond distances $(\AA)$ for 4: Pd1 - C15 1.935(9), Pd1 - S1 2.349(3), Pd1 - S2 2.336(2), Pd1 - N1 2.041(7), Pd1 “N2 2.573(7), N3 - C15 1.157(10); for 5: Pd1 - P1 2.2670(9), Pd1 - S1 2.3256(9), Pd1 - S2 2.3344(9), Pd1 - N2 2.082(3), Pd1 - N1 2.459(3); and for 6: Pd1 - N1 2.1662(14), Pd1 - N2 2.1492(13), Pd1 - C1 2.0466(15), Pd1 - P1 2.2495(4). 


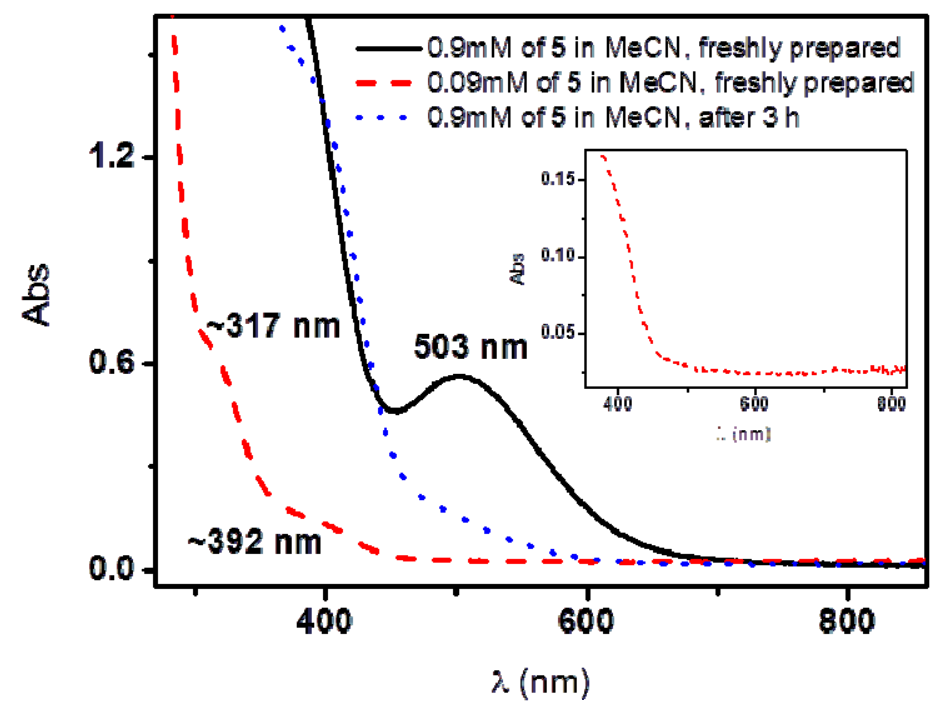

Figure 2. UV-vis spectra of 5 in $\mathrm{MeCN}$. Inset: zoomed-in UV-vis spectrum in the $400-800 \mathrm{~nm}$ range for a freshly prepared $0.09 \mathrm{mM} \mathrm{MeCN}$ solution of $\mathbf{5}$.

\section{Generation and Characterization of (N2S2)Pd ${ }^{\mathrm{I}}$ Intermediates}

The (N2S2)Pd(II) complexes described above were then reacted with 1 equiv of the appropriate reducing agents in $\mathrm{MeCN}$ at $-35{ }^{\circ} \mathrm{C}$ to generate the corresponding $\mathrm{Pd}(\mathrm{I})$ intermediates: $\mathrm{CoCp}_{2}$ was used for complexes $\mathbf{1}-\mathbf{5}$, and $\mathrm{CoCp}_{2}{ }_{2}$ was used for $\mathbf{6}$. Excitingly, all reaction mixtures of the reduction of complexes $\mathbf{1}-\mathbf{6}$ exhibit axial or pseudo-axial signals in their EPR spectra, suggesting the presence of odd-electron species (Figure 3). Based on the simulation of the EPR data, for the $\left[(\mathrm{N} 2 \mathrm{~S} 2) \mathrm{Pd}^{\mathrm{I}} \mathrm{X}\right]^{\mathrm{n}+}\left(\mathrm{X}=\mathrm{Me}\right.$ 2-Pd ${ }^{\mathrm{I}}, \mathrm{Cl}$ 3-Pd ${ }^{\mathrm{I}}, \mathrm{n}=0 ; \mathrm{X}=\mathrm{MeCN}$ 1-Pd $\mathbf{d}^{\mathbf{I}}, \mathrm{tBuNC}$ 4-Pd ${ }^{\mathbf{I}}, \mathrm{n}=1$ ) complexes similar superhyperfine coupling constants to the axial pyridine $\mathrm{N}$ atom in the $g_{z}$ region were detected, suggesting a $\left(\mathrm{d}_{x 2-\mathrm{y} 2}\right)^{1}$ ground state for the $\operatorname{Pd}(\mathrm{I})$ centers (Figure 3 and Table 1), which should still adopt a square pyramidal geometry with the 
N2S2 ligand in the $\kappa^{3}$ conformation. The slightly rhombic EPR spectrum of $\mathbf{2}-\mathbf{P d}^{\mathbf{I}}$ could indicate that there is a slight distortion in the equatorial plane. By comparison, the EPR spectrum of the $\left[(\mathrm{N} 2 \mathrm{~S} 2) \mathrm{Pd}^{\mathrm{I}}\left(\mathrm{PPh}_{3}\right)\right]^{+}$species $\left(\mathbf{5}-\mathbf{P d}^{\mathrm{I}}\right)$ shows no discernible superhyperfine coupling constants to the $\mathrm{N}$ atom(s), implying that upon reduction to $\mathrm{Pd}(\mathrm{I})$ the coordination environment has changed from square pyramidal to a trigonal geometry, with N2S2 ligand adopting a with $\kappa^{2}$ conformation, and the two $\mathrm{N}$ atom donors and the $\mathrm{P}$ atom binding in the equatorial plane, while the two $\mathrm{S}$ atoms are likely no longer coordinated to the Pd center. Similarly, no superhyperfine coupling to $\mathrm{N}$ or $\mathrm{P}$ atoms was observed for the $(\mathrm{N} 2 \mathrm{~S} 2) \mathrm{Pd}^{\mathrm{I}} \mathrm{Me}\left(\mathrm{PPh}_{3}\right)$ species $(\mathbf{6}-\mathrm{Pd})$, in agreement with the $\kappa^{2}$ conformation of $\mathrm{N} 2 \mathrm{~S} 2$ in $\mathbf{6}$. Overall, all observed $g$ values are consistent with previously reported $\mathrm{Pd}(\mathrm{I}) \mathrm{d}^{9}$ species with the $g_{a v e}>2.0023,{ }^{16}$ confirming that the unpaired electron resides on the Pd center rather than on the ligand(s). ${ }^{10}$ To further investigate the reactivity of these $\mathrm{Pd}(\mathrm{I})$ complexes, ${ }^{1} \mathrm{H}$ NMR was employed to monitor the reduction of $\mathbf{2}$ and $\mathbf{6}$ by $\mathrm{CoCp}_{2}$ and $\mathrm{CoCp}^{*}{ }^{*}$, respectively, to reveal that except for the formation of a small amount of $(\mathrm{N} 2 \mathrm{~S} 2) \mathrm{Pd}^{\mathrm{II}} \mathrm{Me}_{2}(<10 \%)$, the majority of the products are $\mathrm{Pd}(0)$ black, free $\mathrm{N} 2 \mathrm{~S} 2$ ligand, and small amounts of unidentified decomposition products. ${ }^{17}$

Table 1. Parameters Used for the Simulation of EPR Spectra of Pd(I) Species

\begin{tabular}{lllllll}
\hline \multirow{2}{*}{ Species } & \multicolumn{2}{l}{$g$ value } & & \multicolumn{4}{l}{ Superhyperfine coupling $(\mathrm{G})$} \\
\cline { 2 - 7 } & $g_{x}$ & $g_{y}$ & $g_{z}$ & $A(x, x)$ & $A(y, y)$ & $A(z, z)$ \\
\hline $\mathbf{1 - P d}^{\mathbf{I}}$ & 2.0023 & 2.0023 & 2.0870 & $\mathrm{ND}^{a}$ & $\mathrm{ND}$ & $A_{N}(1 N)=19.0$ \\
$\mathbf{2 - P d}^{\mathbf{I}}$ & 1.9983 & 2.0085 & 2.0770 & $\mathrm{ND}$ & $\mathrm{ND}$ & $A_{N}(1 N)=14.5$ \\
3-Pd $^{\mathbf{I}}$ & 2.0023 & 2.0023 & 2.0857 & $\mathrm{ND}$ & $\mathrm{ND}$ & $A_{N}(1 N)=16.0$ \\
4-Pd $^{\mathbf{I}}$ & 2.0023 & 2.0023 & 2.0820 & $\mathrm{ND}$ & $\mathrm{ND}$ & $A_{N}(1 N)=19.0$ \\
$\mathbf{5 - P d}^{\mathbf{I}}$ & 1.9986 & 2.0023 & 2.0993 & $\mathrm{ND}$ & $\mathrm{ND}$ & $\mathrm{ND}$ \\
\hline
\end{tabular}




\begin{tabular}{lllllll}
\hline 6-Pd & & & \\
& 2.0019 & 2.0032 & 2.0713 & ND & ND & ND \\
8-Pd $^{\mathbf{I}}$ & 1.9965 & 2.0063 & 2.0853 & ND & ND & ND \\
9-Pd $^{\mathbf{I}}$ & 1.9982 & 2.0080 & 2.0810 & ND & ND & ND \\
\hline
\end{tabular}

${ }^{a} \mathrm{ND}=$ Not detected. 

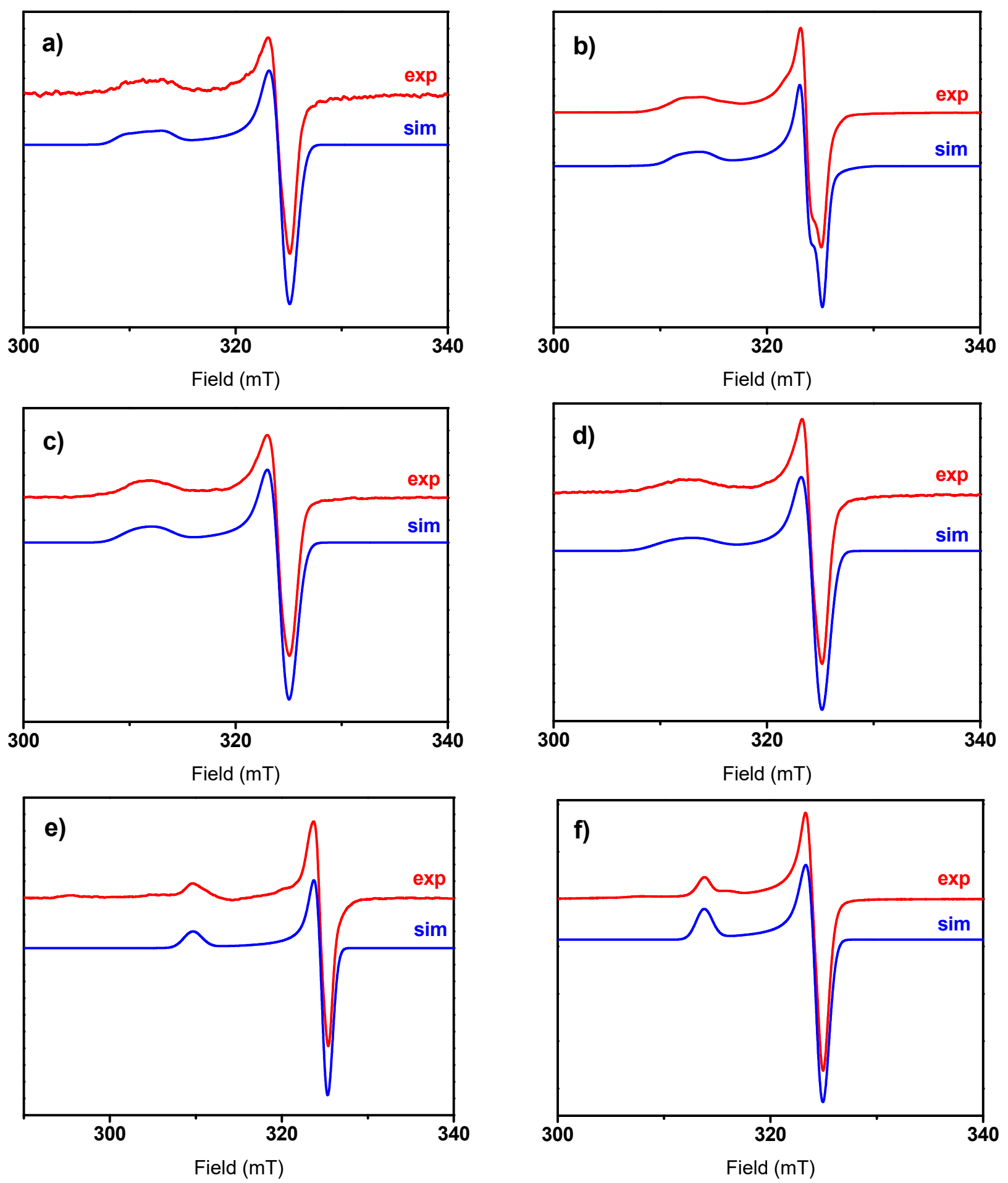

Figure 3. Experimental and simulated EPR spectra of reaction mixtures of (N2S2) $\mathrm{Pd}^{\mathrm{II}}$ complexes and reducing agents at $77 \mathrm{~K}$ in 1:3 MeCN:PrCN frozen glass: a-e) $\mathbf{1}-\mathbf{5}+\mathrm{CoCp}_{2}$; f) $\mathbf{6}$ $+\mathrm{CoCp}^{*}$ 
We have also monitored the chemical reduction of the (N2S2)Pd ${ }^{\mathrm{II}}$ complexes by UV-vis spectroscopy. The UV-vis spectra of the reaction mixture of 4 and $\mathrm{CoCp}_{2}$ in $\mathrm{MeCN}$ at $-35{ }^{\circ} \mathrm{C}$ exhibits an absorption band at $452 \mathrm{~nm}$ (Figure 4), suggesting the formation of a $\operatorname{Pd}(\mathrm{I})$ intermediate 4-Pd ${ }^{\mathbf{I}}$, which was further confirmed by the corresponding EPR spectrum (Figure 3d). Both UV-vis and EPR spectra show that the corresponding signals of the 4-Pd ${ }^{\mathbf{I}}$ species decrease within several minutes. ${ }^{17}$ Monitoring of the decay of the absorbance band at $452 \mathrm{~nm}$ implies reveals a a first order decay process with a rate constant of $0.656 \mathrm{~min}^{-1}$, and this instability of the $4-\mathbf{P d}^{\mathbf{I}}$ complex at $-35{ }^{\circ} \mathrm{C}$ prevented any isolation attempts.
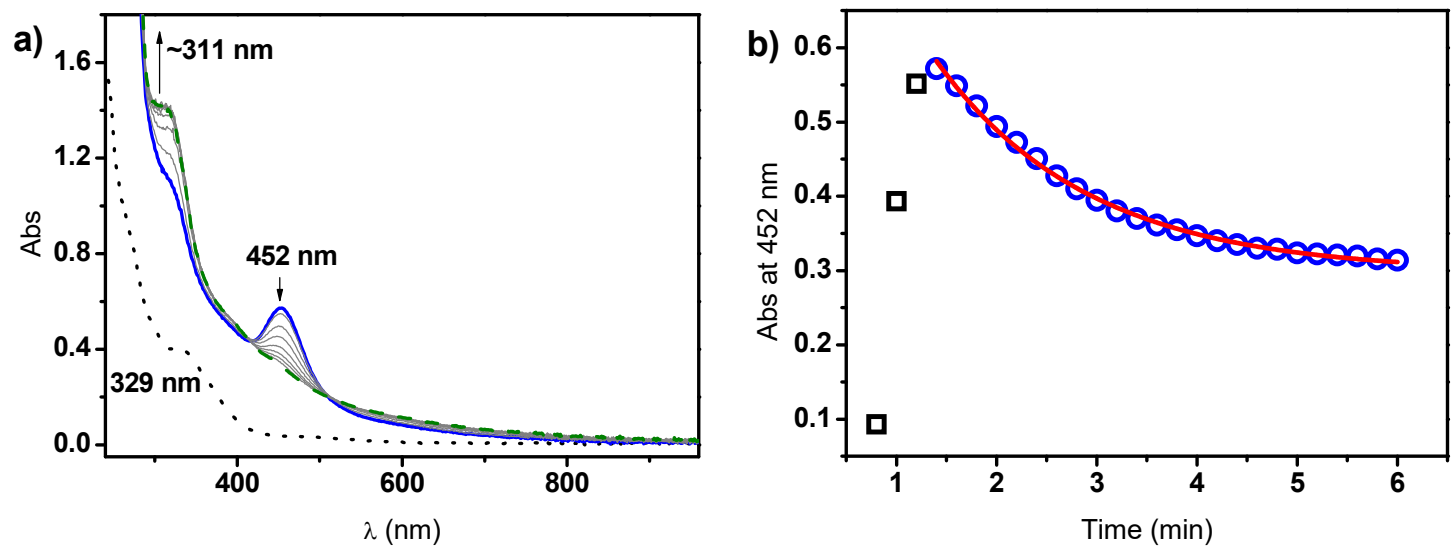

Figure 4. a) UV-vis spectra of the reduction of $4(0.12 \mathrm{mM}$, black dotted line $)$ with 1 equiv $\mathrm{CoCp} 2$ in $\mathrm{MeCN}$ at $-35^{\circ} \mathrm{C}$ : (thick blue solid line) spectrum at 1 min after adding $\mathrm{CoCp}_{2}$; (thick green dashed line) spectrum after $5 \mathrm{~min}$; (thin solid lines) time interval $=0.4 \mathrm{~min} . \mathrm{b}$ ) The kinetic fitting of the absorbance decay at $452 \mathrm{~nm}$. Squares: $0.8-1.4 \mathrm{~min}$; circles: $1.4-6 \mathrm{~min}$; solid line: $1^{\text {st }}$ order decay fitting with the rate constant $\mathrm{k}=0.656 \mathrm{~min}^{-1}\left(\mathrm{R}^{2}=0.998\right)$. 
Interestingly, the bulk electrolysis reduction of $\mathbf{4}$ under an inert atmosphere at room temperature yields a robust diamagnetic $\mathrm{Pd}(\mathrm{I})$ dinuclear complex $\left[(\mathrm{N} 2 \mathrm{~S} 2) \mathrm{Pd}^{\mathrm{I}}(\mu-\mathrm{BuNC})\right]_{2}\left(\mathrm{ClO}_{4}\right)_{2}$ (7), which was isolated as orange crystals. The X-ray crystal structure of 7 shows that each $\operatorname{Pd}(\mathrm{I})$ center adopts a pseudo-square pyramidal geometry, with one N2S2 ligand binding in a $\kappa^{3}$ comformation, two bridging tBuNC ligands, and one $\mathrm{Pd}(\mathrm{I})-\mathrm{Pd}(\mathrm{I})$ bond: the two $\mathrm{N}$ donor atoms and the two tBuNC ligands define the equatorial plane, while one $\mathrm{S}$ donor atom weakly interacts in the axial position (Figure 5). To the best of our knowledge, there is only one other tBuNC bridged complex that has been reported to date: $\left[(\mathrm{tBuNC})_{2} \mathrm{Cu}_{2} \mathrm{I}_{2}(\mathrm{dppm})_{2}(\mu-\mathrm{CNtBu})\right](\mathrm{BF} 4)_{2} .{ }^{18}$ The bond length of $\mathrm{CN}$ of the bridged tBuNC group in 7 is $1.162 \AA$, slightly longer than the reported bridged $\mathrm{C}-\mathrm{N}$ bond length $(1.141 \AA)$ in the $\mathrm{Cu}(\mathrm{I})$ complex, but significantly shorter than the average bond distance of a $\mathrm{C}=\mathrm{N}$ double bond $(1.279 \AA) .{ }^{19}$ Given that this $\mathrm{C}-\mathrm{N}$ bond length it is also comparable to that of the terminal tBuNC ligand in $4(1.157 \AA)$ and the other reported complexes with terminal tBuNC groups, ${ }^{20}$ it suggests that the bonding interaction between the tBuNC ligand and the Pd center should not be defined as a " $\mathrm{Pd}^{\mathrm{II}}-\left(\mathrm{tBuNC} \mathrm{C}^{-}\right)$" system containing a redox non-innocent tBuNC ligand. Therefore, the observed diamagnetism of 7 is likely due to the antiferromagnetic coupling between the two $\operatorname{Pd}(\mathrm{I})$ centers, with the bond distance of $\operatorname{Pd}(\mathrm{I})-\operatorname{Pd}(\mathrm{I})$ $(2.7416 \AA)$ comparable but slightly longer $(0.04-0.14 \AA)$ than other reported $\operatorname{Pd}(\mathrm{I})-\mathrm{Pd}(\mathrm{I})$ bonding interactions. ${ }^{11 a}$, 21 While the Pd- $\mathrm{N}_{\text {ave }}$ bond length is comparable to other $\left(\kappa^{2}-\mathrm{N} 2 \mathrm{~S} 2\right) \mathrm{Pd}^{\mathrm{II}}$ complexes, the Pd-S bond (2.6588 $\AA$ ) is significantly longer than that in $\mathbf{4}$, likely due to the conformation change between 4 in which the two $\mathrm{S}$ atoms interact in the equatorial plane, while in 7 one $\mathrm{S}$ atom occupies an axial position with an elongated bonding interaction. In addition, the Pd- $\mathrm{C}_{\text {ave }}$ bond distance $(2.035 \AA)$ is slightly longer than that in $\mathbf{4}$, as a result of the bridging ligation of tBuNC. Since the dinuclear Pd(I) complex 7 was formed upon the reduction of the 
mononuclear Pd(II) complex 4, we wanted to proble whether the formation of 7 involves the transient formation of the 4-Pd ${ }^{\mathbf{I}}$ species, however the analysis of the electrolysis solution by EPR at different time points did not reveal the presence of paramagnetic species, suggesting that on the time scale of the electroreduction process at room temperatute any $4-\mathbf{P d}^{\mathrm{I}}$ species formed will dimerize rapidly to form 7 .

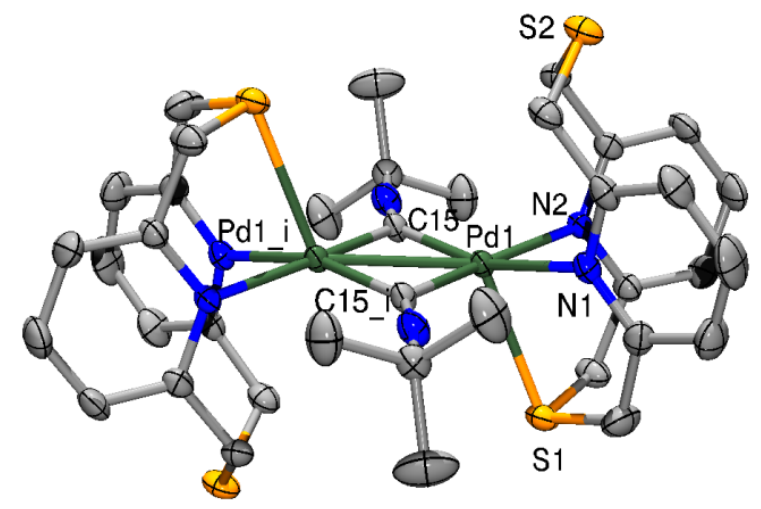

Figure 5. ORTEP diagram for 7 with $50 \%$ thermal ellipsoids and the perchlorate counteranions and $\mathrm{H}$ atoms were omitted for clarity. Selected bond distances $(\AA ̊)$ : Pd1 - N1 2.220(2), Pd1 - N2 2.217(2), Pd1 - C15 1.994(3), Pd1 - C15_i 2.076(3), Pd1 - S1 2.6588(8), Pd1 - Pd1_i 2.7416(5), N3 - C15 1.162(4).

\section{Characterization of ( $\left.{ }^{\mathrm{tBu}} \mathrm{N} 4\right) \mathrm{Pd}{ }^{\mathrm{I}}$ Species}

Since the ${ }^{\text {tBu}} \mathrm{N} 4$ ligand was shown to stabilize paramagnetic Pd(III) complexes, ${ }^{2 \mathrm{i}}$ we also wanted to probe the possibility of employing such a ligand system for stabilizing $\operatorname{Pd}(\mathrm{I})$ species as a mean to support a potential $\operatorname{Pd}(\mathrm{I}) / \mathrm{Pd}(\mathrm{III})$ catalytic cycle for chemical transformations. The $\left[\left({ }^{(\mathrm{Bu}} \mathrm{N} 4\right) \mathrm{Pd}^{\mathrm{II}}(\mathrm{tBuNC})_{2}\right](\mathrm{OTf})_{2}$ complex (9) was obtained as pink crystals by reacting $\left[\left({ }^{(\mathrm{Bu}} \mathrm{N} 4\right) \mathrm{Pd}^{\mathrm{II}}(\mathrm{MeCN})_{2}\right](\mathrm{OTf})_{2}(\mathbf{8})^{22}$ with 2 equiv tBuNC in $\mathrm{MeCN}$ (Scheme 2$)$. The X-ray crystal 
structure reveals that the $\mathrm{Pd}(\mathrm{II})$ center has a distorted octahedral coordination geometry, similar to the structure of 8 : the ${ }^{\mathrm{tBu}} \mathrm{N} 4$ ligand adopts a $\mathrm{\kappa}^{4}$ conformation with an axial elongation for the two amine $\mathrm{N}$ donor atoms, while the two tBuNC ligands are cis-positioned in the equatorial place along with the two pyridine $\mathrm{N}$ donor atoms (Figure 6). The average $\mathrm{Pd}-\mathrm{N}_{\mathrm{py}}$ bond length (2.061 $\AA$ ) and the average $\mathrm{Pd} \cdots \mathrm{N}_{\mathrm{tBu}}$ distance $(2.612 \AA)$ are consistent with the previously reported values for $8,{ }^{22}$ while the average Pd-CNtBu distance $(1.950 \AA)$ is slightly shorter that the average PdNCMe distance in $\mathbf{8}$, like due to the stronger donating ability of tBuNC vs. MeCN.

Scheme 2. Synthesis and Reduction of the $\left({ }^{\mathrm{tBu}} \mathrm{N} 4\right) \mathrm{Pd}$ Complexes
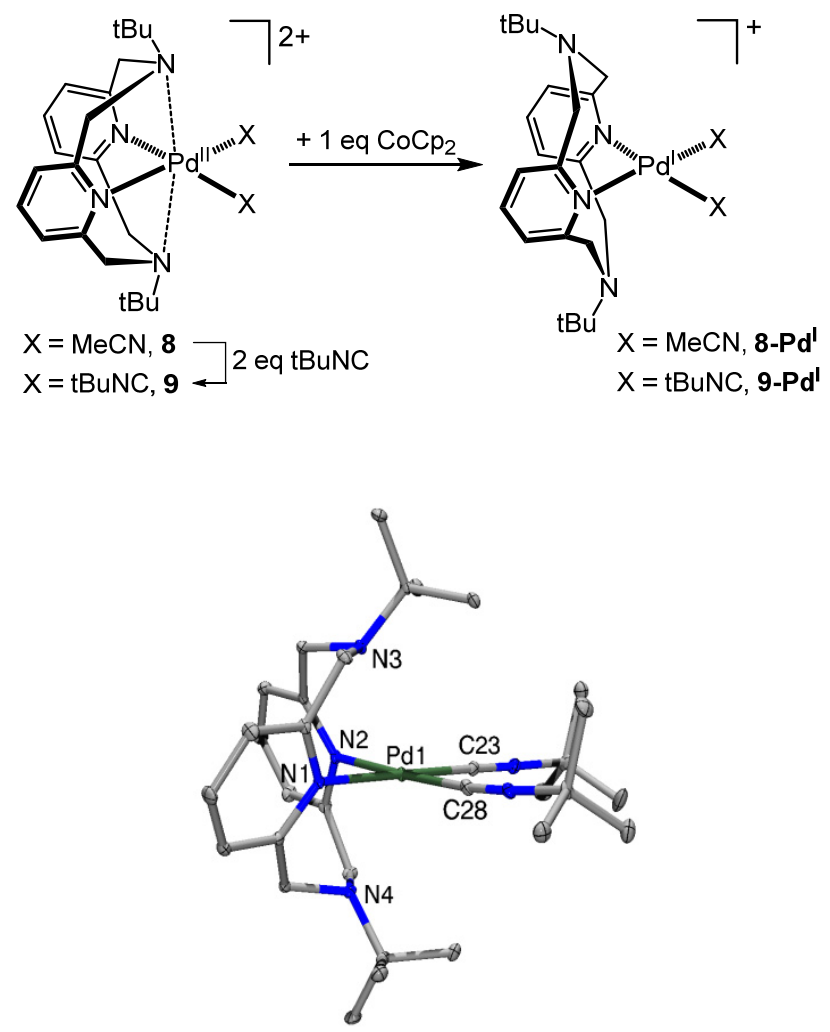

Figure 6. ORTEP diagram for the cation of 9 with $50 \%$ thermal ellipsoids and the triflate counteranions and $\mathrm{H}$ atoms omitted for clarity. Selected bond distances $(\AA)$ for 9: Pd1 - N1 


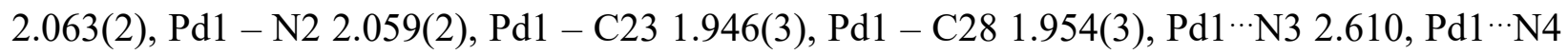
2.614 .

Upon the chemical reduction of 8 and 9 by 1 equiv $\mathrm{CoCp}_{2}$ at $-35^{\circ} \mathrm{C}$ in $\mathrm{MeCN}: \operatorname{PrCN}(1: 3, \mathrm{v}: \mathrm{v})$, the $\left.\left[{ }^{\mathrm{tBu}} \mathrm{N} 4\right) \mathrm{Pd}^{\mathrm{I}} \mathrm{X}_{2}\right]^{+}$species $\left(\mathrm{X}=\mathrm{MeCN}, \mathbf{8}-\mathbf{P d}{ }^{\mathrm{I}} ; \mathrm{X}=\mathrm{tBuNC}, \mathbf{9}-\mathbf{P d} \mathbf{d}^{\mathrm{I}}\right)$ were observed by EPR, although the EPR signal for 8-Pd ${ }^{\mathrm{I}}$ was quite faint (Figure 7 and Table 1). The axial pattern of the EPR spectra suggests that both $\operatorname{Pd}(\mathrm{I})$ centers exhibit a $\left(\mathrm{d}_{\mathrm{x} 2-\mathrm{y} 2}\right)^{1}$ ground state, and the absence of $\mathrm{N}$ superhyperfine coupling from the ${ }^{\mathrm{tBu}} \mathrm{N}$ groups to the $\mathrm{Pd}(\mathrm{I})$ center implies that upon the $1 \mathrm{e}^{-}$ reduction, the interaction with the axial $\mathrm{N}$ atoms is, that is the conformation of the ${ }^{\mathrm{tBu}} \mathrm{N} 4$ ligand might change from $\kappa^{4}$ to $\kappa^{2}$. To further probe this conformational change, we have performed DFT calculations for the 4-Pd ${ }^{\mathbf{I}}, \kappa^{4}-\mathbf{9 -}-\mathbf{P d} \mathbf{d}^{\mathbf{I}}$, and $\kappa^{2}-\mathbf{9}-\mathbf{P} \mathbf{d}^{\mathbf{I}}$ species and analyzed the interactions between the axial $\mathrm{N}$ atoms and the $\mathrm{Pd}(\mathrm{I})$ centers (Table 2). ${ }^{17}$ When comparing the atomic orbital contributions to the frontier molecular orbitals of these complexes, for $\mathbf{4}-\mathbf{P d} \mathbf{d}^{\mathbf{I}}$ a $5 \%$ contribution from the axial pyridine $\mathrm{N}$ atom to the $\beta$ lowest unoccupied molecular orbital (LUMO) was obtained, supporting the observed superhyperfine coupling to the axial $\mathrm{N}$ in the EPR spectrum of 4-Pd ${ }^{\mathbf{I}}$. By comparison, for both $\kappa^{4}-\mathbf{9}-\mathbf{P d}^{\mathbf{I}}$, and $\kappa^{2}-\mathbf{9}-\mathbf{P d}^{\mathbf{I}}$ species in which the ${ }^{\mathrm{tBu}} \mathrm{N} 4$ ligand adopts $\kappa^{4}$ and $\kappa^{2}$ conformations, respectively, no contribution to the $\beta$ LUMO from the axial $\mathrm{N}$ atomic orbitals was observed (Table 2), supporting the absence of any appreciable superhyperfine coupling to the axial $\mathrm{N}$ atoms. In addition, the EPR signal intensities for both 4-Pd ${ }^{\mathrm{I}}$ and $\mathbf{9 - P d ^ { \mathrm { I } }}$

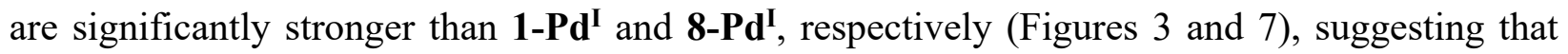
the presence of tBuNC stabilizes to a greater extent the $\mathrm{Pd}(\mathrm{I})$ center. 

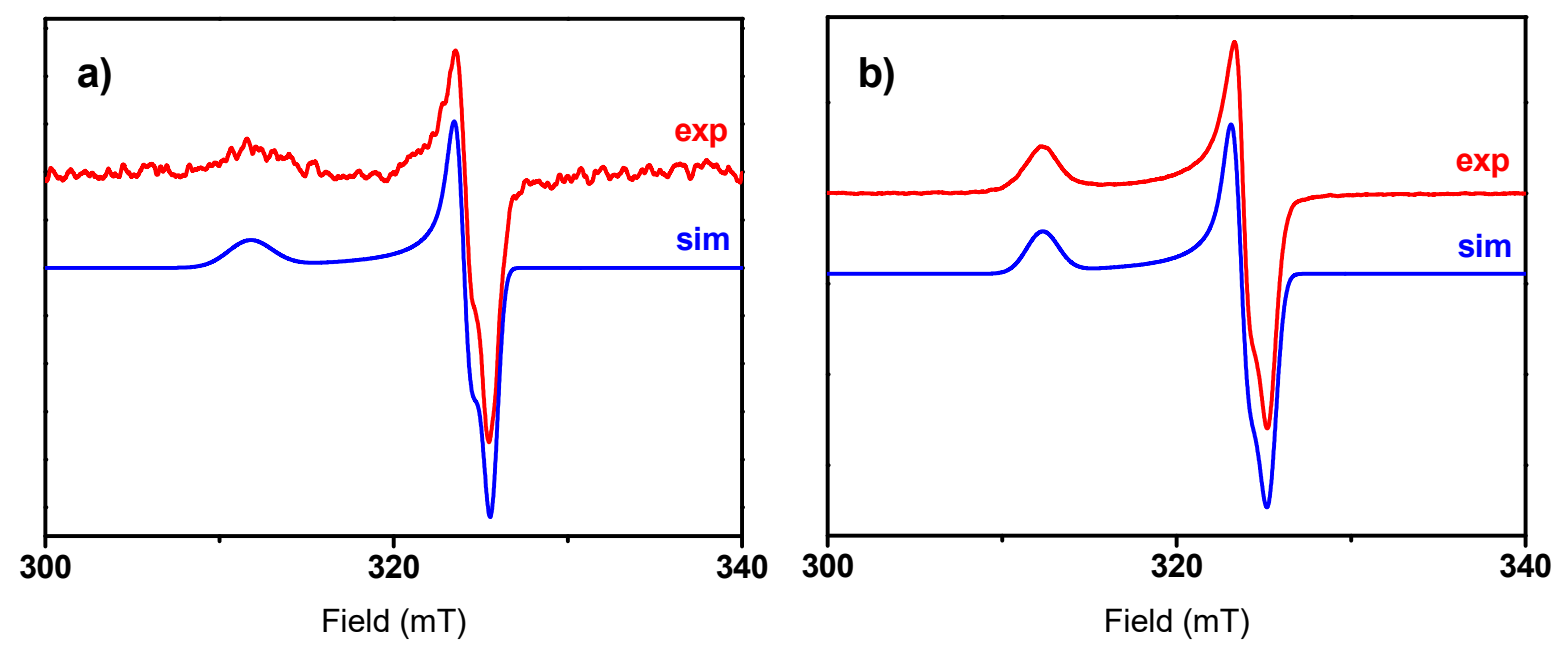

Figure 7. Experimental and simulated EPR spectra of reaction mixtures of $\left({ }^{\mathrm{tBu}} \mathrm{N} 4\right) \mathrm{Pd}^{\mathrm{II}}$ complexes 8 and 9 with 1 equiv $\mathrm{CoCp}_{2}$ at $77 \mathrm{~K}$ in $1: 3 \mathrm{MeCN}: \operatorname{PrCN}$ frozen glass: a) $8+\mathrm{CoCp}_{2}$; b) $9+$ CoCp2. The parameters used for the simulations can be found in Table 1 .

Table 2. Comparison of the $\beta$ lowest unoccupied molecular orbitals (LUMOs) of 4-Pd ${ }^{\mathrm{I}}, \kappa^{4}-\mathbf{9}-$ $\mathbf{P d}^{\mathrm{I}}$, and $\kappa^{2}$-9-Pd ${ }^{\mathrm{I}}$ complexes

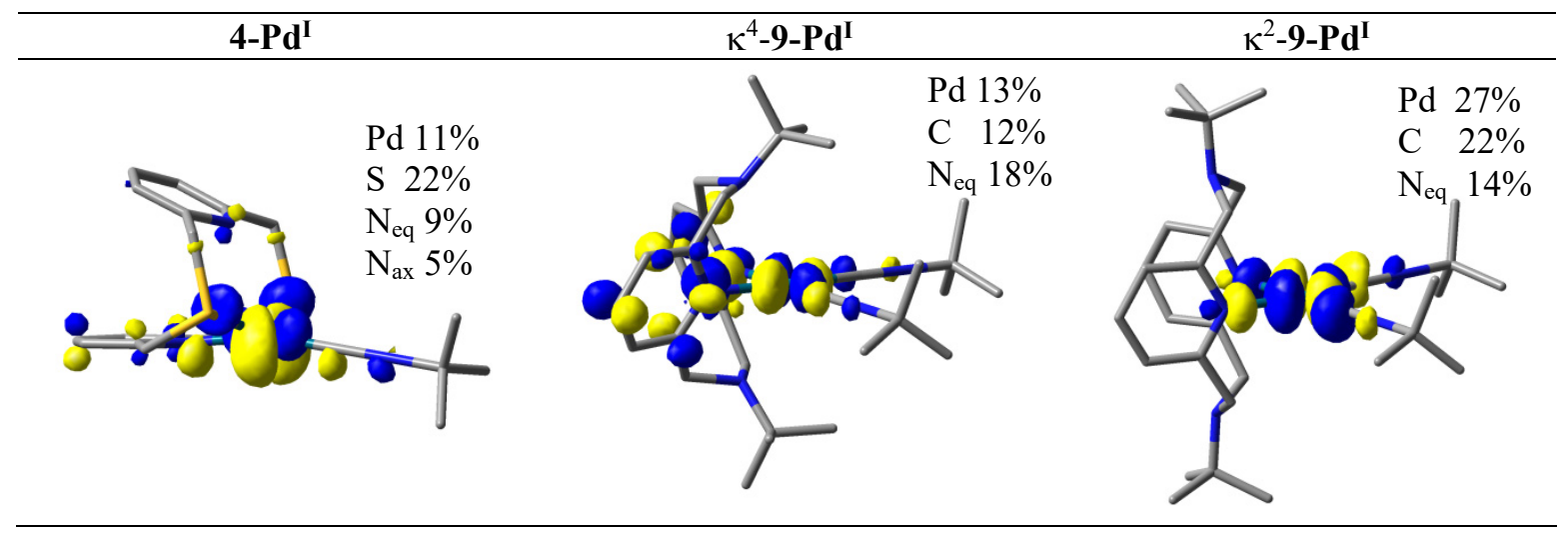

Palladium K-edge X-ray absorption spectroscopy (XAS), which involves excitation of Pd 1s electrons, has been shown to be an effective qualitative means of probing the oxidation state for 
a systematic series of Pd complexes. ${ }^{23}$ Since the EPR spectrum of 8-Pd $\mathbf{P d}^{\mathrm{I}}$ reveals a weak signal, to further probe the presence of a $\mathrm{Pd}(\mathrm{I})$ center we have obtained XAS spectra for MeCN solutions of 8-Pd ${ }^{\mathrm{I}}$, the $\mathrm{Pd}(\mathrm{I})$ reference compound $\left[\mathrm{Pd}_{2}^{\mathrm{I}}(\mathrm{MeCN})_{6}\right]^{2+},{ }^{24}$ as well as the $\mathrm{Pd}(\mathrm{II})$ precursor $\left[\left({ }^{\mathrm{tBu}} \mathrm{N} 4\right) \mathrm{Pd}^{\mathrm{II}}(\mathrm{MeCN})_{2}\right]^{2+}$ (8) and the $\mathrm{Pd}(\mathrm{III})$ species $\left[\left({ }^{(\mathrm{Bu}} \mathrm{N} 4\right) \mathrm{Pd}^{\mathrm{III}}(\mathrm{MeCN})_{2}\right]^{3+}$ formed upon electrochemical oxidation of 8 (Figure 8 ). ${ }^{22}$ Interestingly, an increase in the edge energy is observed with increasing oxidation state of the Pd center, confirming that in this case the XAS edge energy that correlates with the formal oxidation state assignment. Moreover, the edge energy of 8-Pd ${ }^{\mathrm{I}}$ matches very closely the edge energy observed for $\left[\mathrm{Pd}^{\mathrm{I}}(\mathrm{MeCN})_{6}\right]^{2+}$, supporting the formation of a Pd(I) species upon the reduction of $\mathbf{8}$. The presence of a weak EPR signal for 8-Pd $\mathbf{P d}^{\mathrm{I}}$ could be also due to the formation of a dinuclear $\mathrm{Pd}(\mathrm{I})$ species containing either a $\mathrm{Pd}-\mathrm{Pd}$ bond, commonly observed for $\operatorname{Pd}(\mathrm{I})$ complexes, or in which the two $\operatorname{Pd}(\mathrm{I})$ centers are antiferromagnetically coupled through bridgind ligand(s), similar to 7 (vide supra).

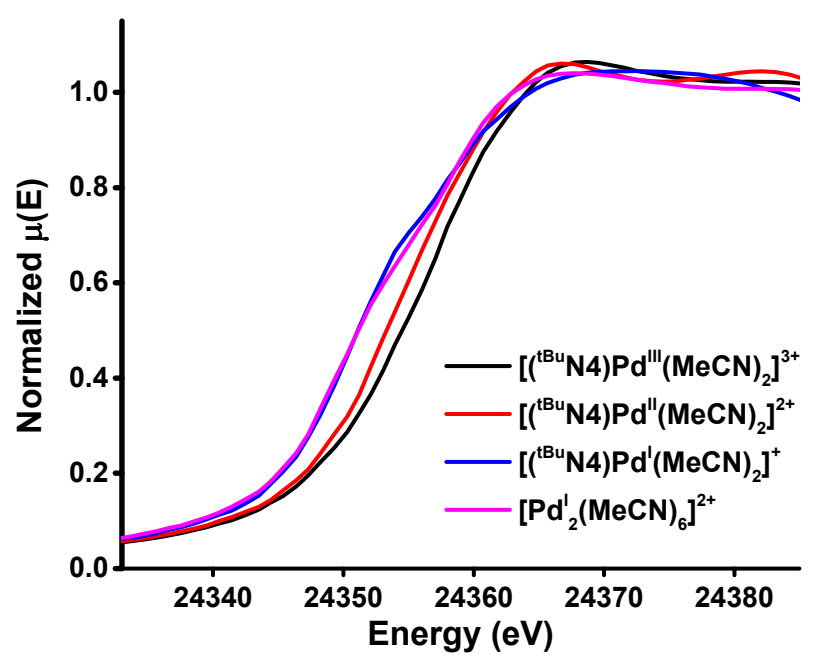

Figure 8. The edge region of the $\mathrm{X}$-ray absorption spectra for $\mathbf{8}-\mathbf{P d}{ }^{\mathrm{I}}$, the $\mathrm{Pd}(\mathrm{I})$ reference compound $\left.\left[\mathrm{Pd}_{2}{ }_{2}(\mathrm{MeCN})_{6}\right]^{2+},{ }^{24} \quad\left[{ }^{(\mathrm{B} u} \mathrm{N} 4\right) \mathrm{Pd}^{\mathrm{II}}(\mathrm{MeCN})_{2}\right]^{2+} \quad(8)$, and the $\mathrm{Pd}(\mathrm{III})$ species

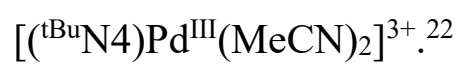




\section{CONCLUSION}

In summary, reported herein is a thorough spectroscopic characterization of a series of $(\mathrm{N} 2 \mathrm{~S} 2) \mathrm{Pd}^{\mathrm{I}}$ and $\left({ }^{\mathrm{tBu}} \mathrm{N} 4\right) \mathrm{Pd}^{\mathrm{I}}$ complexes. We have shown that the $\mathrm{Pd}(\mathrm{I})$ oxidation state is accessible for all the studied Pd(II) complexes via either chemical or electrochemical reduction. EPR, UVvis, and X-ray absorption spectroscopy provide direct evidence for the presence of $\operatorname{Pd}(\mathrm{I})$ intermediates, for which the stability was further improved with the assistance of a series of softer isonitrile and phosphine ligands. The proposed structures based on the simulations of the EPR data was further corroborated by DFT calculations. Moreover, an uncommon diamagnetic $\operatorname{Pd}(\mathrm{I})-\mathrm{Pd}(\mathrm{I})$ dinuclear species with two bridging tBuNC ligands was isolated via electrochemical reduction of $\mathbf{4}$ and structurally characterized. Taking advantage of these results, we are currently further optimizing the reactions conditions and the ligands employed for isolating a range of mononuclear $\operatorname{Pd}(\mathrm{I})$ complexes, with the goal of investigating in detail their stoichiometric reactivity and catalytic applications.

\section{EXPERIMENTAL DETAILS}

\section{Ligand and Metal Complex Syntheses}

Reagents and Materials. All chemicals were commercially available from Aldrich, Fisher or Strem Chemicals and were used as received without further purification. 2,11dithia[3.3](2,6)pyridinophane $\quad(\mathrm{N} 2 \mathrm{~S} 2),{ }^{6}, \quad$ 14a, $\quad 25 \quad N, N^{\prime}$-ditertbutyl-2,11-diaza[3.3]-(2,6)pyridinophane $\left({ }^{\mathrm{tBu}} \mathrm{N} 4\right),{ }^{26} \quad\left[(\mathrm{~N} 2 \mathrm{~S} 2) \mathrm{Pd}^{\mathrm{II}}(\mathrm{MeCN})\right]_{2}(\mathrm{OTf})_{2} \quad(\mathbf{1}),{ }^{12} \quad\left[(\mathrm{~N} 2 \mathrm{~S} 2) \mathrm{Pd}^{\mathrm{II}} \mathrm{Me}\right]_{2}(\mathrm{OTf})_{2} \quad(\mathbf{2}),{ }^{12}$ $\left[(\mathrm{N} 2 \mathrm{~S} 2) \mathrm{Pd}^{\mathrm{II}} \mathrm{Cl}\right](\mathrm{OTf})(3),{ }^{6 \mathrm{e}}$ and $\left.\left[{ }^{\mathrm{tBu}} \mathrm{N} 4\right) \mathrm{Pd}^{\mathrm{II}}(\mathrm{MeCN})_{2}\right](\mathrm{OTf})_{2}(\mathbf{8})^{22}$ were prepared according to the literature procedures. Solvents were purified prior to use by passing through a column of 
activated alumina using an MBraun solvent purification system. On the basis of their reduction potential, ${ }^{27}$ either cobaltocene $(\mathrm{CoCp} 2)$ or bis(pentamethyl)cyclopentadienyl cobalt(II) $\left(\mathrm{CoCp}_{2}\right)$ was used as a reducing agent.

[(N2S2)Pd"(tBuNC)](OTf)2, 4. 2 equiv tBuNC $(8.1 \mu \mathrm{L}, 70.2 \mu \mathrm{mol})$ were added via a microsyringe to an $\mathrm{MeCN}$ solution $(2 \mathrm{~mL})$ of $\left[(\mathrm{N} 2 \mathrm{~S} 2) \mathrm{Pd}^{\mathrm{II}}(\mathrm{MeCN})\right]_{2}(\mathrm{OTf}) 4(50.4 \mathrm{mg}, 35.0 \mu \mathrm{mol})$ while stirring. The solution changed color from brown to red immediately. After $1 \mathrm{~h}$, the solvent was removed under vacuum and the resulting red oil was stored at $-20^{\circ} \mathrm{C}$ for $1 \mathrm{~h}$, to give a needle-shaped red crystalline product. Yield: $52.8 \mathrm{mg}, 89 \% .{ }^{1} \mathrm{H}$ NMR $\left(\mathrm{CD}_{3} \mathrm{CN}, 300 \mathrm{MHz}\right), \delta$ (ppm): $1.66(\mathrm{~s}, 9 \mathrm{H}, \mathrm{tBu}), 4.62\left(\mathrm{~d}, J=16.5 \mathrm{~Hz}, 4 \mathrm{H}, \mathrm{CH}_{2}\right), 5.08\left(\mathrm{~d}, J=16.5 \mathrm{~Hz}, 4 \mathrm{H}, \mathrm{CH}_{2}\right), 7.24(\mathrm{~d}$, $\left.J=7.8 \mathrm{~Hz}, 4 \mathrm{H}, \mathrm{Py} \mathrm{H}_{\text {meta }}\right), 7.62$ (t, $\left.J=8.1 \mathrm{~Hz}, 2 \mathrm{H}, \mathrm{Py} \mathrm{H}_{\text {para }}\right) . \mathrm{UV}$-vis $\left(\mathrm{MeCN} ; \lambda, \mathrm{nm}\left(\varepsilon, \mathrm{M}^{-1} \mathrm{~cm}^{-}\right.\right.$ 1)): 327 (3200), 497 (200). Elemental analysis: found, C 34.06, H 2.98, N 6.40\%; calculated $\mathrm{C}_{21} \mathrm{H}_{23} \mathrm{~F}_{6} \mathrm{~N}_{3} \mathrm{O}_{6} \mathrm{PdS}_{4} \cdot 0.5 \mathrm{CH}_{3} \mathrm{CN}, \mathrm{C} 33.76, \mathrm{H} 3.16, \mathrm{~N} 6.26 \%$. ESI-MS (m/z): 462.0314, calculated for $\left[(\mathrm{N} 2 \mathrm{~S} 2) \mathrm{Pd}^{\mathrm{II}}(\mathrm{tBuNC})-\mathrm{H}^{+}\right]^{+}: 462.0290$.

[(N2S2)Pd $\left.{ }^{\mathrm{II}}\left(\mathbf{P P h}_{3}\right)\right](\mathbf{O T f})_{2}$, 5. 2 equiv $\mathrm{PPh}_{3}(10.2 \mathrm{mg}, 39.0 \mu \mathrm{mol})$ was dissolved in $2 \mathrm{~mL}$ of $\mathrm{MeCN}$ and added to an $\mathrm{MeCN}$ solution $(2 \mathrm{~mL})$ of $\left[(\mathrm{N} 2 \mathrm{~S} 2) \mathrm{Pd}^{\mathrm{II}}(\mathrm{MeCN})\right]_{2}(\mathrm{OTf})_{4}(28.1 \mathrm{mg}, 19.5$ $\mu \mathrm{mol})$ while stirring. The solution changed color from brown to red immediately. After $1 \mathrm{~h}$, the mixture was set up for crystallization with anhydrous diethyl ether vapor diffusion at RT. A needle-shaped red crystalline product formed after 1 2 days. Yield: $29.9 \mathrm{mg}, 82 \%$. ${ }^{1} \mathrm{H}$ NMR $\left(\mathrm{CD}_{3} \mathrm{CN}, 300 \mathrm{MHz}\right), \delta(\mathrm{ppm}): 4.42\left(\mathrm{~d}, J=16.5 \mathrm{~Hz}, 4 \mathrm{H}, \mathrm{CH}_{2}\right), 4.58\left(\mathrm{~d}, J=16.2 \mathrm{~Hz}, 4 \mathrm{H}, \mathrm{CH}_{2}\right)$, 7.18 (d, $J=7.8 \mathrm{~Hz}, 4 \mathrm{H}$, Py Heta), 7.59 (t, $J=7.8 \mathrm{~Hz}, 2 \mathrm{H}$, Py $\mathrm{H}_{\text {para }}$ ), $7.6-7.9$ (m, 15H, Ph). UVvis $\left(\mathrm{MeCN} ; \lambda, \mathrm{nm}\left(\varepsilon, \mathrm{M}^{-1} \mathrm{~cm}^{-1}\right)\right): 317$ (sh, 6600), 392 (sh, 1360), 503 (630). Elemental analysis: found, C 43.66, H 2.96, N 4.00\%; calculated $\mathrm{C}_{34} \mathrm{H}_{29} \mathrm{~F}_{6} \mathrm{~N}_{2} \mathrm{O}_{6} \mathrm{PPdS}_{4} \cdot 0.5 \mathrm{CH}_{3} \mathrm{CN}, \mathrm{C} 43.71, \mathrm{H} 3.20, \mathrm{~N}$ 3.64\%. ESI-MS (m/z): 321.0275, calculated for $\left[(\mathrm{N} 2 \mathrm{~S} 2) \mathrm{Pd}^{\mathrm{II}}\left(\mathrm{PPh}_{3}\right)\right]^{2+}: 321.0273$. 
[(N2S2)Pd $\left.{ }^{\mathrm{II}} \mathbf{M e}\left(\mathbf{P P h}_{3}\right)\right]$ (OTf), 6. A $0.5 \mathrm{~mL} \mathrm{MeCN}$ solution of 2 equiv $\mathrm{PPh}_{3}(8.2 \mathrm{mg}, 31.2$ $\mu \mathrm{mol})$ was added dropwise to an $\mathrm{MeCN}$ solution $(2 \mathrm{~mL})$ of $\left[(\mathrm{N} 2 \mathrm{~S} 2) \mathrm{Pd}^{\mathrm{II}} \mathrm{Me}\right]_{2}(\mathrm{OTf})_{2}(17.0 \mathrm{mg}$, $15.6 \mu \mathrm{mol})$ while stirring. Solution changed color from orange to light yellow immediately. After $0.5 \mathrm{~h}$, the mixture was set up for crystallization with diethyl ether vapor diffusion at room temperature. Square shaped colorless crystalline formed after 1 2 days. Yield: $15.0 \mathrm{mg}, 60 \% .{ }^{1} \mathrm{H}$

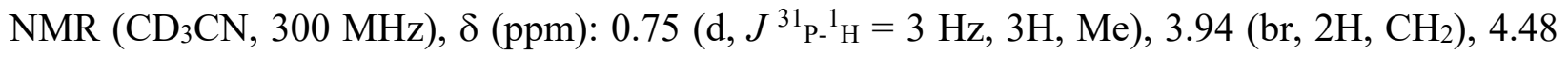
(br, 2H, $\mathrm{CH}_{2}$ ), 4.92 (br, 2H, $\mathrm{CH}_{2}$ ), 5.30 (br, 2H, $\mathrm{CH}_{2}$ ), 7.00 (br, 2H, Py Hmeta), 7.4-7.6 (m, 15H, Ph), 7.77 (br, $\left.1 \mathrm{H}, \mathrm{Py} \mathrm{H}_{\text {para }}\right)$. Another set of $\mathrm{Py} \mathrm{H}_{\text {meta }}$ and $\mathrm{H}_{\text {para }}$ peaks are buried under the peak coressponding to the $\mathrm{Ph}$ groups. UV-vis $\left(\mathrm{MeCN} ; \lambda, \mathrm{nm}\left(\varepsilon, \mathrm{M}^{-1} \mathrm{~cm}^{-1}\right)\right.$ ): 292 (1300), $\sim 320$ (sh, 430), 406 (sh, 20). Elemental analysis: found, C 50.67, H 3.61, N 3.42\%; calculated $\mathrm{C}_{34} \mathrm{H}_{32} \mathrm{~F}_{3} \mathrm{~N}_{2} \mathrm{O}_{3} \mathrm{PPdS}_{3}, \mathrm{C} 50.59, \mathrm{H} 4.00, \mathrm{~N} 3.47 \%$. ESI-MS (m/z): 657.0784, calculated for $\left[(\mathrm{N} 2 \mathrm{~S} 2) \mathrm{Pd}^{\mathrm{II}} \mathrm{Me}\left(\mathrm{PPh}_{3}\right)\right]^{+}: 657.0779$.

$\left[(\mathbf{N} 2 S 2) \mathbf{P d}^{\mathrm{I}}(\mu-\mathrm{tBuNC})\right]_{2}\left(\mathrm{ClO}_{4}\right)_{2}$, 7. Electrochemical reduction of $\left[(\mathrm{N} 2 \mathrm{~S} 2) \mathrm{Pd}^{\mathrm{II}}(\mathrm{tBuNC})\right](\mathrm{OTf}) 2$ $(27.7 \mathrm{mg}, 36.3 \mu \mathrm{mol})$ was performed in $10 \mathrm{~mL} 0.1 \mathrm{M}\left(\mathrm{Bu}_{4} \mathrm{~N}\right) \mathrm{ClO}_{4}$ in $\mathrm{MeCN}$ at RT under $\mathrm{N}_{2}$. The color changed from red to yellowish orange during the electrolysis. After the charge corresponding to $1 \mathrm{e}^{-}$reduction has passed, the electrolysis was stopped and the solution was concentrated to $\sim 1 \mathrm{~mL}$ under vacuum. The resulted orange solution was stored at $-35{ }^{\circ} \mathrm{C}$ for several days. Orange needle shaped crystals were collected by filtration and washed with pentane. Yield: $6.3 \mathrm{mg}, 30 \% .{ }^{1} \mathrm{H}$ NMR $\left(\mathrm{CD}_{3} \mathrm{CN}, 300 \mathrm{MHz}\right), \delta(\mathrm{ppm}): 0.75(\mathrm{~s}, 18 \mathrm{H}, t \mathrm{Bu}), 4.55(\mathrm{~d}$, $\left.J=15.9 \mathrm{~Hz}, 8 \mathrm{H}, \mathrm{CH}_{2}\right), 4.95\left(\mathrm{br}, J=15.9 \mathrm{~Hz}, 8 \mathrm{H}, \mathrm{CH}_{2}\right), 7.30$ (d, $\left.J=6.9 \mathrm{~Hz}, 8 \mathrm{H}, \mathrm{Py} \mathrm{H}_{\text {meta }}\right), 7.70$ (t, br, $J=7.2 \mathrm{~Hz}, 4 \mathrm{H}$, Py Hpara). UV-vis $\left(\mathrm{MeCN} ; \lambda\right.$, nm $\left.\left(\varepsilon, \mathrm{M}^{-1} \mathrm{~cm}^{-1}\right)\right): 365$ (3400). Elemental analysis: found, $\mathrm{C} 42.12, \mathrm{H} 4.13, \mathrm{~N} 8.90 \%$; calculated $\mathrm{C}_{40} \mathrm{H}_{48} \mathrm{Cl}_{2} \mathrm{~N}_{6} \mathrm{O}_{8} \mathrm{Pd}_{2} \mathrm{~S}_{4} \cdot 1.5 \mathrm{CH}_{3} \mathrm{CN}, \mathrm{C} 42.53$, H 4.36, N 8.65\%. ESI-MS (m/z): 463.0359, calculated for [(N2S2) $\left.\operatorname{Pd}^{\mathrm{I}}(\mathrm{tBuNC})\right]^{+}: 463.0368$. 
$\left[\left(^{\left({ }^{B u}\right.} \mathbf{N} 4\right) P^{\mathrm{II}}(\mathbf{t B u N C})_{2}\right](\mathbf{O T f})_{2}, 9.2$ equiv tBuNC $(5.4 \mu \mathrm{L}, 47.7 \mu \mathrm{mol})$ were added through a microsyringe to an $\mathrm{MeCN}$ solution $(1 \mathrm{~mL})$ of $\left[\left({ }^{\mathrm{tBu}} \mathrm{N} 4\right) \mathrm{Pd}^{\mathrm{II}}(\mathrm{MeCN})_{2}\right](\mathrm{OTf})_{2}(20.1 \mathrm{mg}, 24.0 \mu \mathrm{mol})$ while stirring. Solution changed color from blue to pink immediately. After $30 \mathrm{~min}$, the solvent was removed and the resulting pink crystalline solid was dried under vacuum. Yield: $22.0 \mathrm{mg}$, 100\%. ${ }^{1} \mathrm{H}$ NMR (CD 3 CN, $\left.300 \mathrm{MHz}\right), \delta(\mathrm{ppm}): 1.46$ (s, 18H, $\left.t B u-\mathrm{NC}\right), 1.47$ (s, 18H, tBu-N4), $3.57\left(\mathrm{~d}, J=17.1 \mathrm{~Hz}, 4 \mathrm{H}, \mathrm{CH}_{2}\right), 4.64\left(\mathrm{~d}, J=17.4 \mathrm{~Hz}, 4 \mathrm{H}, \mathrm{CH}_{2}\right), 7.31(\mathrm{~d}, J=8.1 \mathrm{~Hz}, 4 \mathrm{H}, \mathrm{Py}$ $\mathrm{H}_{\text {meta) }}$ ) 7.85 (t, $J=8.1 \mathrm{~Hz}, 2 \mathrm{H}$, Py Hpara). UV-vis (MeCN; $\left.\lambda, \mathrm{nm}\left(\varepsilon, \mathrm{M}^{-1} \mathrm{~cm}^{-1}\right)\right): 489$ (70), 343 (sh, 250). Elemental analysis: found, $\mathrm{C} 44.08, \mathrm{H} 4.93, \mathrm{~N} 8.98 \%$; calculated $\mathrm{C}_{34} \mathrm{H}_{50} \mathrm{~F}_{6} \mathrm{~N}_{6} \mathrm{O}_{6} \mathrm{PdS}_{2}, \mathrm{C}$ 44.23, H 5.46, N 9.10\%. ESI-MS (m/z): 229.0833, calculated for $\left.\left[{ }^{(\mathrm{Bu}} \mathrm{N} 4\right) \mathrm{Pd}^{\mathrm{II}}\right]^{2+}: 229.0831$; 270.6199 , calculated for $\left[\left({ }^{(\mathrm{Bu}} \mathrm{N} 4\right) \mathrm{Pd}^{\mathrm{II}}(\mathrm{tBuNC})\right]^{2+}: 270.6199 ; 312.1567$, calculated for

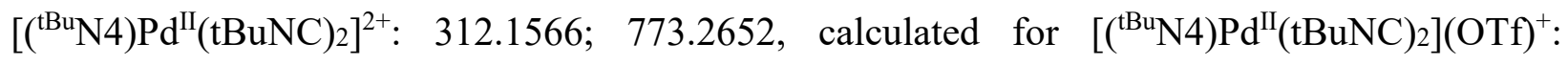
773.2652.

\section{Physical Measurements}

General methods. ${ }^{1} \mathrm{H}(300.121 \mathrm{MHz})$ NMR spectra were recorded on a Varian Mercury-300 spectrometer. Low temperature $\left(-20^{\circ} \mathrm{C}\right){ }^{1} \mathrm{H}(600 \mathrm{MHz}) \mathrm{NMR}$ spectra were recorded on a Varian Unity Inova-600 spectrometer. Chemical shifts are reported in ppm and referenced to residual solvent resonance peaks. Abbreviations for the multiplicity of NMR signals are s (singlet), d (doublet), t (triplet), q (quartet), sep (septet), m (multiplet), br (broad). UV-vis spectra were recorded on a Varian Cary 50 Bio spectrophotometer. EPR spectra were recorded on a JEOL JES-FA X-band (9.2 GHz) EPR spectrometer in MeCN $: \operatorname{PrCN}(v: v=1: 3)$ frozen glass at 77 K. Simulation of EPR spectra were performed using WinEPR SimFonia v.1.25. Elemental analyses were carried out by the Columbia Analytical Services Tucson Laboratory. ESI-MS experiments were performed on a Bruker Maxis QTOF mass spectrometer with an electron spray 
ionization source. ESI mass-spectrometry was provided by Washington University Mass Spectrometry Resource, a NIH Research Resource (Grant No. P41RR0954).

Electrochemical Measurements. Electrochemical grade $(\mathrm{Bu} 4 \mathrm{~N}) \mathrm{ClO}_{4}$ purchased from Aldrich was used as the supporting electrolyte. Cyclic voltammetry was performed with a BASi EC Epsilon electrochemical workstation or a CHI 660D Electrochemical Analyzer. Electrochemical measurements were carried out under a flow of nitrogen, and the analyzed solutions were deaerated by purging with nitrogen. A glassy carbon electrode (GCE, $d=1.6 \mathrm{~mm}$ ) was used as the working electrode, while a Pt wire was used as the auxiliary electrode. The non-aqueous reference electrode containing $\mathrm{Ag} / 0.01 \mathrm{M} \mathrm{AgNO}_{3}$ in $0.1 \mathrm{M} \mathrm{Bu} 4 \mathrm{NClO}_{4} / \mathrm{MeCN}$ was calibrated against $\mathrm{Fc}$; the potential of the $\mathrm{Fc}^{+} / \mathrm{Fc}$ couple vs. $\mathrm{Ag} / 0.01 \quad \mathrm{M} \mathrm{AgNO}_{3} / 0.1 \mathrm{M} \mathrm{Bu} 4 \mathrm{NClO}_{4} / \mathrm{MeCN}$ reference electrode is $+0.105 \mathrm{~V}$.

EPR Studies of the Formation of Pd(I) Species. An EPR tube was charged with a solution of $\operatorname{Pd}$ complex in $\mathrm{MeCN}: \operatorname{PrCN}(\mathrm{v}: \mathrm{v}=1: 3)$ and cooled down to $-70{ }^{\circ} \mathrm{C}$. Another solution containing 1 equiv of chemical reducing agent in the same solvent mixture was quickly added via a microsyringe, followed by a quick shake of the tube, and then the sample was frozen in the liquid nitrogen. An initial EPR spectrum was taken at $77 \mathrm{~K}$. If necessary, the sample was then carefully warmed up for 10-30 s to allow for the complete reaction to occur, refrozen, and the EPR spectrum was recorded again.

\section{Computational Studies}

The density functional theory (DFT) calculations were performed with the program package Gaussian 09. ${ }^{28}$ The B3LYP functional was employed, ${ }^{29}$ and the Stevens $(\mathrm{CEP}-31 \mathrm{G})^{30}$ valence basis set and effective core potential were used for $\mathrm{Pd},{ }^{31}$ which have been shown previously to reproduce well experimental parameters of Pd complexes. ${ }^{32}$ The geometry optimization 
calculations used were performed for the cations of $\mathbf{4 - P d ^ { I }}, \boldsymbol{\kappa}^{\mathbf{4}}-\mathbf{9}-\mathbf{P d} \mathbf{d}^{\mathbf{I}}$, and $\boldsymbol{\kappa}^{\mathbf{2}} \mathbf{- 9}-\mathbf{P d} \mathbf{d}^{\mathbf{I}}$, based on the crystallographic coordinates of the cations of $\mathbf{4}, \mathbf{9}$, and a proposed conformation of $\boldsymbol{\kappa}^{\mathbf{2}} \mathbf{- 9}$, respectively. The ground state wavefunctions were investigated by analysis of the frontier MOs, and the atomic contributions to MOs were calculated using the program Chemissian. ${ }^{33}$ TD-DFT calculations were employed to obtain the predicted absorption bands and their major contribution

transitions for 4-Pd ${ }^{\mathbf{I}}$. The calculated UV-vis spectrum was generated using GaussSum, ${ }^{34}$ with a full width at half maximum (FWHM) value of $3,000 \mathrm{~cm}^{-1}$.

\section{X-ray Absorption Spectroscopy Studies}

The X-ray absorption spectroscopy (XAS) measurements were conducted at Argonne National Laboratory (Argonne, IL), at the Advanced Photon Source (ring energy $=7.0 \mathrm{GeV}$ ) on the 10-ID beamline of the Materials Research Collaborative Access Team (MRCAT). The samples were loaded into a custom-designed, chemically resistant PEEK cell fitted with a cap with a Swagelok VCR fitting and a hand-tightened O-ring seal. ${ }^{23 a}$ The temperature and air-sensitive samples were loaded under a nitrogen blanket in a dry ice bath. The solution measurements were made in emission mode. The experiments utilized a cryogenically cooled double-crystal Si(111) monochromator in conjunction with a glass coated mirror to minimize the presence of harmonics The monochromator was scanned continuously from $-200 \mathrm{eV}$ to $+800 \mathrm{eV}$ relative to the $\mathrm{Pd} k$ edge energy. Scans were taken with a $\mathrm{Pd}^{0}$ foil reference $(24352.6 \mathrm{eV})$ for energy correction during data analysis (see below).

XAS Spectral Processing and Analysis. The program Athena (Athena Ravel REF) was used to process the XANES spectra. The sample and $\mathrm{Pd}$ foil reference spectra were imported, and background removal and normalization was performed. Then, the Pd foil reference for every sample spectrum was energy corrected by selecting the maximum in the first derivative, finding 
the zero crossing in the second derivative, and setting the energy of the zero crossing to 24352.6 $\mathrm{eV}$. The energy corrected Pd foil reference spectra were then aligned to have all sample data on the same absolute energy grid for analysis purposes.

\section{X-ray Diffraction Studies}

Crystals of X-ray diffraction quality were obtained by slow anhydrous diethyl ether vapor diffusion into acetonitrile solutions. Suitable crystals of appropriate dimensions were mounted on Mitgen loops in random orientations. Preliminary examination and data collection were performed using a Bruker Kappa Apex-II Charge Coupled Device (CCD) Detector system single crystal X-ray diffractometer equipped with an Oxford Cryostream LT device. Data were collected using graphite monochromated Mo K $\alpha$ radiation $(\lambda=0.71073 \AA)$ from a fine focus sealed tube X-ray source. Preliminary unit cell constants were determined with a set of 36 narrow frame scans. Typical data sets consist of a combination of $\varpi$ and $\phi$ scan frames with typical scan width of $0.5^{\circ}$ and counting time of $15-30$ seconds/frame at a crystal to detector distance of $\sim 4.0 \mathrm{~cm}$. The collected frames were integrated using an orientation matrix determined from the narrow frame scans. Apex II and SAINT software packages were used for data collection and data integration. ${ }^{35}$ Analysis of the integrated data did not show any decay. Final cell constants were determined by global refinement of reflections from the complete data set. Data were corrected for systematic errors using SADABS based on the Laue symmetry using equivalent reflections. ${ }^{35}$

Supporting Information. Reactivity studies of reduction of 2 and 6 by ${ }^{1} \mathrm{H}$ NMR, timedependent EPR spectra of the mixture of $\mathbf{4}$ and $\mathrm{CoCp}$ 2, computational details, and X-ray crystal structure data. 


\section{Acknowledgements}

We thank the Department of Energy's BES Catalysis Science Program (DE-SC0006862) for financial support. We also thank Drs. Jeffrey T. Miller and Ryan C. Nelson (Argonne National Lab) for assistance with obtaining the XAS data, and Dr. Jason Schultz for assistance with the EPR measurements.

\section{Corresponding Author}

*E-mail: mirica@illinois.edu

\section{ORCID}

Liviu Mirica: 0000-0003-0584-9508

\section{Conflicts of interest}

There are no conflicts to declare.

\section{Notes and references}

1 (a) E. Negishi, Handbook of Organopalladium Chemistry for Organic Synthesis, John Wiley \& Sons, Hoboken, NJ, 2002; (b) J.F. Hartwig, Organotransition Metal Chemistry: From Bonding to Catalysis, University Science Books, Sausalito, 2010.

2 (a) T.W. Lyons and M.S. Sanford, Palladium-Catalyzed Ligand-Directed C-H Functionalization Reactions, Chem. Rev., 2010, 110, 1147-1169; (b) K. Muñiz, HighOxidation-State Palladium Catalysis: New Reactivity for Organic Synthesis, Angew. Chem., Int. Ed., 2009, 48, 9412-9423; (c) A. Canty, J., Organopalladium and platinum chemistry in oxidising milieu as models for organic synthesis involving the higher oxidation states of palladium, J. Chem. Soc., Dalton Trans., 2009, 10409-10417; (d) X. Chen, K.M. Engle, D.H. Wang and J.Q. Yu, Palladium(II)-Catalyzed C-H Activation/C-C Cross-Coupling Reactions: Versatility and Practicality, Angew. Chem., Int. Ed., 2009, 48, 5094-5115; (e) P. Sehnal, R.J.K. Taylor and I.J.S. Fairlamb, Emergence of Palladium(IV) Chemistry in Synthesis and Catalysis, Chem. Rev., 2010, 110, 824-889; (f) L.V. Desai, K.L. Hull and M.S. Sanford, Palladium-catalyzed oxygenation of unactivated $\mathrm{sp}(3) \mathrm{C}-\mathrm{H}$ bonds, J. Am. Chem. Soc., 2004, 126, 9542-9543; (g) L.-M. Xu, B.-J. Li, Z. Yang and Z.-J. Shi, Organopalladium(iv) chemistry, Chem. Soc. Rev., 2010, 39, 712-733; (h) D.C. Powers 
and T. Ritter, Palladium(III) in Synthesis and Catalysis, Top. Organomet. Chem., 2011, 35, 129-156; (i) J.R. Khusnutdinova, N.P. Rath and L.M. Mirica, Stable Mononuclear Organometallic $\mathrm{Pd}(\mathrm{III})$ Complexes and Their C-C Bond Formation Reactivity, J. Am. Chem. Soc., 2010, 132, 7303-7305.

3 A.R. Dick, K.L. Hull and M.S. Sanford, A highly selective catalytic method for the oxidative functionalization of C-H bonds, J. Am. Chem. Soc., 2004, 126, 2300-2301.

4 D.C. Powers and T. Ritter, Bimetallic Pd(III) complexes in palladium-catalysed carbonheteroatom bond formation, Nature Chem., 2009, 1, 302-309.

5 (a) J.M. Racowski, A.R. Dick and M.S. Sanford, Detailed Study of C-O and C-C BondForming Reductive Elimination from Stable C2N2O2-Ligated Palladium(IV) Complexes, J. Am. Chem. Soc., 2009, 131, 10974-10983; (b) M.P. Lanci, M.S. Remy, W. Kaminsky, J.M. Mayer and M.S. Sanford, Oxidatively Induced Reductive Elimination from $((\mathrm{t}) \mathrm{Bu}(2)$ bpy)Pd(Me)(2): Palladium(IV) Intermediates in a One-Electron Oxidation Reaction, J. Am. Chem. Soc., 2009, 131, 15618-15620; (c) N.D. Ball, J.W. Kampf and M.S. Sanford, Aryl-CF3 Bond-Forming Reductive Elimination from Palladium(IV), J. Am. Chem. Soc., 2010, 132, 2878-2879; (d) J.M. Racowski and M.S. Sanford, CarbonHeteroatom Bond-Forming Reductive Elimination from Palladium(IV) Complexes, Top. Organomet. Chem., 2011, 35, 61-84; (e) J.M. Racowski, N.D. Ball and M.S. Sanford, C-H Bond Activation at Palladium(IV) Centers, J. Am. Chem. Soc., 2011, 133, 18022-18025; (f) D.C. Powers, E. Lee, A. Ariafard, M.S. Sanford, B.F. Yates, A.J. Canty and T. Ritter, Connecting Binuclear Pd(III) and Mononuclear Pd(IV) Chemistry by Pd-Pd Bond Cleavage, J. Am. Chem. Soc., 2012, 134, 12002-12009; (g) A. Maleckis, J.W. Kampf and M.S. Sanford, A Detailed Study of Acetate-Assisted C-H Activation at Palladium(IV) Centers, J. Am. Chem. Soc., 2013, 135, 6618-6625; (h) S.R. Neufeldt and M.S. Sanford, Controlling Site Selectivity in Palladium-Catalyzed C-H Bond Functionalization, Acc. Chem. Res., 2012, 45, 936-946; (i) L.M. Mirica and J.R. Khusnutdinova, Structure and electronic properties of Pd(III) complexes, Coord. Chem. Rev., 2013, 299-314.

(a) J.R. Khusnutdinova, N.P. Rath and L.M. Mirica, Dinuclear Palladium(III) Complexes with a Single Unsupported Bridging Halide Ligand: Reversible Formation from Mononuclear Palladium(II) or Palladium(IV) Precursors, Angew. Chem., Int. Ed., 2011, 50, 5532-5536; (b) J.R. Khusnutdinova, N.P. Rath and L.M. Mirica, The Aerobic Oxidation of a $\operatorname{Pd}(\mathrm{II})$ Dimethyl Complex Leads to Selective Ethane Elimination from a $\mathrm{Pd}(\mathrm{III})$ Intermediate, J. Am. Chem. Soc., 2012, 134, 2414-2422; (c) F. Tang, F. Qu, J.R. Khusnutdinova, N.P. Rath and L.M. Mirica, Structural and Reactivity Comparison of Analogous Organometallic Pd(III) and Pd(IV) Complexes, Dalton Trans., 2012, 41, 1404614050; (d) J.R. Khusnutdinova, F. Qu, Y. Zhang, N.P. Rath and L.M. Mirica, Formation of the $\operatorname{Pd}(\mathrm{IV})$ Complex [(Me3tacn)PdIVMe3]+ through Aerobic Oxidation of $(\mathrm{Me} 3 \operatorname{tacn}) \mathrm{PdIIMe} 2 \quad(\mathrm{Me} 3 \operatorname{tacn}=\mathrm{N}, \mathrm{N}$,N''-trimethyl-1,4,7-triazacyclononane), Organometallics, 2012, 31, 4627-4630; (e) J. Luo, N.P. Rath and L.M. Mirica, Oxidative Reactivity of (N2S2)PdRX Complexes $(\mathrm{R}=\mathrm{Me}, \mathrm{Cl} ; \mathrm{X}=\mathrm{Me}, \mathrm{Cl}, \mathrm{Br})$ : Involvement of Palladium(III) and Palladium(IV) Intermediates, Organometallics, 2013, 31, 3343-3353; (f) F. Tang, Y. Zhang, N.P. Rath and L.M. Mirica, Detection of $\operatorname{Pd}(\mathrm{III})$ and $\mathrm{Pd}(\mathrm{IV})$ Intermediates during the Aerobic Oxidative C-C Bond Formation from a $\mathrm{Pd}(\mathrm{II})$ Dimethyl Complex, Organometallics, 2012, 31, 6690-6696.

7 (a) G. Manolikakes and P. Knochel, Radical catalysis of Kumada cross-coupling reactions using functionalized Grignard reagents, Angew. Chem., Int. Ed., 2009, 48, 205-209; (b) Z. 
Weng, S. Teo and T.S.A. Hor, Metal unsaturation and ligand hemilability in Suzuki coupling, Acc. Chem. Res., 2007, 40, 676-684.

(a) S. Fujiwara and M. Nakamura, Electron Spin Resonance of Pd(I) .2. Gamma-Irradiated Single Crystals of K2pdc14 and (Nh4)2pdc14, J. Chem. Phys., 1971, 54, 3378-\&; (b) K. Broadley, G.A. Lane, N.G. Connelly and W.E. Geiger, Electrochemical routes to paramagnetic dinuclear and mononuclear palladium Ï€ complexes stabilized by the pentaphenylcyclopentadienyl ligand, J. Am. Chem. Soc., 1983, 105, 2486-2487; (c) G.A. Lane, W.E. Geiger and N.G. Connelly, Palladium(I) .pi.-radicals. Electrochemical preparation and study of their reaction pathways, J. Am. Chem. Soc., 1987, 109, 402-407.

(a) M.C. MacInnis, J.C. DeMott, E.M. Zolnhofer, J. Zhou, K. Meyer, R.P. Hughes and O.V. Ozerov, Cationic Two-Coordinate Complexes of $\mathrm{Pd}(\mathrm{I})$ and $\mathrm{Pt}(\mathrm{I})$ Have Longer MetalLigand Bonds Than Their Neutral Counterparts, Chem, 2016, 1, 902-920; (b) T. Troadec, S.Y. Tan, C.J. Wedge, J.P. Rourke, P.R. Unwin and A.B. Chaplin, One-Electron Oxidation of $[\mathrm{M}((\mathrm{PBu} 3)-\mathrm{Bu}-\mathrm{t})(2)](\mathrm{M}=\mathrm{Pd}, \mathrm{Pt})$ : Isolation of Monomeric $[\mathrm{Pd}((\mathrm{PBu} 3)-\mathrm{Bu}-\mathrm{t})(2)](+)$ and Redox-Promoted C-H Bond Cyclometalation, Angew. Chem., Int. Ed., 2016, 55, 37543757.

10 D. Fenske and W. Bensmann, Preparation and Crystal Structure of Mononuclear, Paramagnetic Pd and Pt Complexes, Z. Naturforsch., B: Chem. Sci., 1985, 40, 1093-1096.

11 (a) R. Vilar, D.M.P. Mingos and C.J. Cardin, Synthesis and structural characterization of [Pd2( $\mu-\mathrm{Br}) 2(\mathrm{PBut3}) 2]$, an example of a palladium(I)-palladium(I) dimer, Dalton Trans., 1996, 4313-4314; (b) D.P. Hruszkewycz, J. Wu, N. Hazari and C.D. Incarvito, Palladium(I)-bridging allyl dimers for the catalytic functionalization of $\mathrm{CO}_{2}, \mathrm{~J}$. Am. Chem. Soc., 2011, 133, 3280-3283.

12 J. Luo, J.R. Khusnutdinova, N.P. Rath and L.M. Mirica, Unsupported $\mathrm{d}^{8}-\mathrm{d}^{8}$ Interactions in Cationic $\mathrm{Pd}^{\mathrm{II}}$ and $\mathrm{Pt}^{\mathrm{II}}$ Complexes: Evidence for a Significant Metal-Metal Bonding Character, Chem. Comm., 2012, 48, 1532-1534.

13 C. Janiak, A critical account on $\pi-\pi$ stacking in metal complexes with aromatic nitrogencontaining ligands., J. Chem. Soc., Dalton Trans., 2000, 3885-3896.

14 (a) T. Moriguchi, S. Kitamura, K. Sakata and A. Tsuge, Syntheses and Structures of Dichloropalladium(II)(Dithia[3.3]Metadipyridinophane) and Dichloroplatinum(II)(Dithia[3.3]Metadipyridinophane) Complexes, Polyhedron, 2001, 20, 2315-2320; (b) W. de Graaf, J. Boersma, W.J.J. Smeets, A.L. Spek and G. van Koten, Dimethyl(N,N,N',N'-tetramethylethanediamine)palladium(II) and dimethyl[1,2bis(dimethylphosphino)ethane]palladium(II): syntheses, X-ray crystal structures, and thermolysis, oxidative-addition and ligand-exchange reactions, Organometallics, 1989, 8, 2907-2917.

15 (a) Y.-J. Kim, H.-T. Jeon, K.-E. Lee and S.W. Lee, Reactivity of the bis(silyl) palladium(II) complex toward organic isothiocyanates, J. Organomet. Chem., 2010, 695, 2258-2263; (b) S. Kundu, W.W. Brennessel and W.D. Jones, Synthesis and reactivity of new Ni, Pd, and Pt 2,6-bis(di-tert-butylphosphinito)pyridine pincer complexes, Inorg. Chem., 2011, 50, 9443-9453.

16 (a) A.J. Blake, R.O. Gould, T.I. Hyde and M. Schröder, Stabilization of monovalent palladium by tetraaza macrocyles, J. Chem. Soc., Chem. Commun., 1987, 431-433; (b) M. Nakamura and S. Fujiwara, Electron spin resonance of palladium(I). III. Nature of the metal-ligand bonds in square planar complexes of palladium(I), J. Coord. Chem., 1972, 1, 221-227. 
17 See Supporting Information.

18 É. Fournier, F. Lebrun, M. Drouin, A. Decken and P.D. Harvey, Preparation and solid-state characterization of mixed-ligand coordination/organometallic oligomers and polymers of copper(I) and silver(I) using diphosphine and mono- and diisocynide ligands, Inorg. Chem., 2004, 43, 3127-3135.

19 H.A. Frank, O. Kennard, D.G. Watson, L. Brammer, A.G. Orpen and R. Taylor, Table of Bond Lengths determined by X-Ray and Neutron Diffraction. Part I Bond Lengths in Organic Compounds, J. Chem. Soc., Perkin Trans. 2, 1987, S1-S18.

20 (a) J. Vicente, I. Saura-Llamas, C. Crünwald, C. Alcaraz, P.G. Jones and D. Bautista, Palladium-assisted formation of carbon-carbon bonds. Part 10. Insertion reactions of isocyanides into the $\mathrm{Pd}-\mathrm{C}$ bond of orthopalladated primary amines. Synthesis of 2-Raminoisoindolinium salts $(\mathrm{R}=\mathrm{tBu}, 2,6-X y l y 1)$, Organometallics, 2002, 21, 3587-3595; (b) W. Imhof, H. Görls and K. Halbauer, Tris(tert-butyl isocyanide- $\kappa \mathrm{C})$ carbonyl-nickel $(0)$, Acta Cryst. E, 2008, E64, m1000.

21 (a) V. Srinivas, E. Balaraman, K.V. Sajna and K.C.K. Swamy, Catalyst-free and catalysed addition of $\mathrm{P}(\mathrm{O})-\mathrm{H}$ bonds to allenyl/alkynyl-phosphonates and -phosphane oxides: Use of a robust, recoverable dinuclear palladium(I) catalyst, Eur. J. Org. Chem., 2011, 4222-4230; (b) P.H.M. Budzelaar, P.W.N.M.v. Leeuwen and C.F. Roobeek, [(dppe)Pd $]_{2}\left(\mathrm{SO}_{3} \mathrm{CF}_{3}\right)_{2}$ : A palladium(I) dimer with "side-on" phosphine coordination, Organometallics, 1992, 11, 23 25.

22 J.R. Khusnutdinova, N.P. Rath and L.M. Mirica, The Conformational Flexibility of the Tetradentate Ligand ${ }^{\mathrm{tBu}} \mathrm{N} 4$ is Essential for the Stabilization of $\left.{ }^{\mathrm{tBu}} \mathrm{N} 4\right) \mathrm{Pd}^{\mathrm{III}}$ Complexes, Inorg. Chem., 2014, 53, 13112-13129.

23 (a) R.C. Nelson and J.T. Miller, An introduction to X-ray absorption spectroscopy and its in situ application to organometallic compounds and homogeneous catalysts, Catal Sci Technol, 2012, 2, 461-470; (b) H. Duan, M.H. Li, G.H. Zhang, J.R. Gallagher, Z.L. Huang, Y. Sun, Z. Luo, H.Z. Chen, J.T. Miller, R.Q. Zou, A.W. Lei and Y.L. Zhao, Single-Site Palladium(II) Catalyst for Oxidative Heck Reaction: Catalytic Performance and Kinetic Investigations, ACS Catal., 2015, 5, 3752-3759.

24 T. Murahashi, T. Nagai, T. Okuno, T. Matsutani and H. Kurosawa, Synthesis and ligand substitution reactions of a homoleptic acetonitrile dipalladium(I) complex, Chem. Commun., 2000, 1689-1690.

25 E.C. Constable, A.C. King and P.R. Raithby, Synthesis, coordination chemistry and crystal structures of [2+2] macrocycles incorporating 2,2-bis(thiomethyl)pyridine sub-units, Polyhedron, 1998, 17, 4275-4289.

26 C.M. Che, Z.Y. Li, K.Y. Wong, C.K. Poon, T.C.W. Mak and S.M. Peng, A simple synthetic route to N,N'-dialkyl-2,11-diaza[3.3](2,6)pyridinophanes. Crystal structures of N,N'-di-tert-butyl-2,11-diaza[3.3](2,6)pyridinophane and its copper(II) complex, Polyhedron, 1994, 13, 771-776.

27 N.G. Connelly and W.E. Geiger, Chemical Redox Agents for Organometallic Chemistry, Chem. Rev., 1996, 96, 877-910.

28 M. J. Frisch, H. B. Schlegel, G. E. Scuseria, M. A. Robb, J. R. Cheeseman, G. Scalmani, V. Barone, B. Mennucci, G. A. Petersson, H. Nakatsuji, M. Caricato, X. Li, H. P. Hratchian, A. F. Izmaylov, J. Bloino, G. Zheng, J. L. Sonnenberg, M. Hada, M. Ehara, K. Toyota, R. Fukuda, J. Hasegawa, M. Ishida, T. Nakajima, Y. Honda, O. Kitao, H. Nakai, T. Vreven, J. A. Montgomery, Jr., J. E. Peralta, F. Ogliaro, M. Bearpark, J. J. Heyd, E. Brothers, K. N. 
Kudin, V. N. Staroverov, R. Kobayashi, J. Normand, K. Raghavachari, A. Rendell, J. C. Burant, S. S. Iyengar, J. Tomasi, M. Cossi, N. Rega, J. M. Millam, M. Klene, J. E. Knox, J. B. Cross, V. Bakken, C. Adamo, J. Jaramillo, R. Gomperts, R. E. Stratmann, O. Yazyev, A. J. Austin, R. Cammi, C. Pomelli, J. W. Ochterski, R. L. Martin, K. Morokuma, V. G. Zakrzewski, G. A. Voth, P. Salvador, J. J. Dannenberg, S. Dapprich, A. D. Daniels, O. Farkas, J. B. Foresman, J. V. Ortiz, J. Cioslowski, D. J. Fox,, Gaussian 09, Revision A.02, Gaussian, Inc., Wallingford CT, 2009.

29 (a) A.D. Becke, A New Mixing of Hartree-Fock and Local Densisty-Functional Theories, J. Chem. Phys., 1993, 98, 1372-1377; (b) C.T. Lee, W.T. Yang and R.G. Parr, Development of the Colle-Salvetti Correlation-Energy Formula into a Functional of the Electron-Density, Phys. Rev. B: Condens. Matter Mater. Phys., 1988, 37, 785-789.

30 (a) W.J. Stevens, H. Basch and M. Krauss, Compact Effective Potentials and Efficient Shared-Exponent Basis-Sets for the 1st-row and 2nd-row Atoms, J. Chem. Phys., 1984, 81, 6026-6033; (b) W.J. Stevens, M. Krauss, H. Basch and P.G. Jasien, Relativistic Compact Effective Potentials and Efficient, Shared-Exponent Basis-Sets for the 3rd-row, 4th-row, and 5th-row Atoms, Can. J. Chem., 1992, 70, 612-630.

31 (a) P.J. Hay and W.R. Wadt, Ab initio effective core potentials for molecular calculations potentials for the transition-metal atoms Sc to Hg, J. Chem. Phys., 1985, 82, 270-283; (b) P.J. Hay and W.R. Wadt, Ab initio effective core potentials for molecular calculations potentials for $\mathrm{K}$ to Au including the outermost core orbitals, J. Chem. Phys., 1985, 82, 299310.

32 (a) N.A. Foley, M. Lail, J.P. Lee, T.B. Gunnoe, T.R. Cundari and J.L. Petersen, Comparative reactivity of $\mathrm{TpRu}(\mathrm{L})(\mathrm{NCMe}) \mathrm{Ph}(\mathrm{L}=\mathrm{CO}$ or $\mathrm{PMe} 3)$ : Impact of ancillary ligand $\mathrm{L}$ on activation of carbon-hydrogen bonds including catalytic hydroarylation and hydrovinylation/oligomerization of ethylene, J. Am. Chem. Soc., 2007, 129, 6765-6781; (b) A.S. Veige, L.M. Slaughter, P.T. Wolczanski, N. Matsunaga, S.A. Decker and T.R. Cundari, Deoxygenations of (silox)(3)WNO and R3PO by (silox)(3)M (M = V, Ta) and $($ silox $)(3) \mathrm{NbL}($ silox $=(\mathrm{Bu} 3 \mathrm{SiO})-\mathrm{Bu}-\mathrm{t})$ : Consequences of electronic effects, J. Am. Chem. Soc., 2001, 123, 6419-6420.

33 Chemissian, version 4.60, 2018, www.chemissian.com, accessed June 2019.

34 N.M. O'Boyle, A.L. Tenderholt and K.M. Langner, cclib: A library for packageindependent computational chemistry algorithms, J. Comput. Chem., 2008, 29, 839-845.

35 Bruker Analytical X-Ray, Madison, WI, 2010 
TOC Graphic

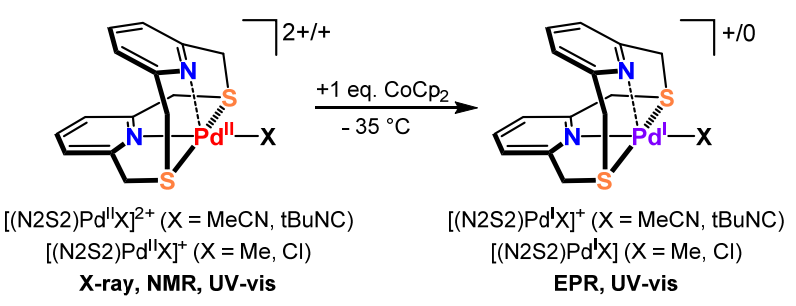

Several mononuclear Pd(I) complexes supported by N2S2 and tBuN4 ligands were generated and characterized by EPR, UV-vis, XAS, and DFT calculations. 